\title{
Effects of two polychaete worms, Nereis diversicolor and Arenicola marina, on aerobic and anaerobic decomposition in a sandy marine sediment
}

\author{
Gary T. Banta*, Marianne Holmer, Mikael H. Jensen**, Erik Kristensen \\ Institute of Biology, Odense University, Campusvej 55, 5230 Odense $\mathrm{M}$, Denmark
}

\begin{abstract}
The effects of 2 polychaete species, Nereis diversicolor and Arenicola marina, on benthic metabolism and decomposition processes in organic-poor $(0.06 \% \mathrm{POC})$, sandy sediment were experimentally investigated. Sediment $\mathrm{O}_{2}$ uptake and $\mathrm{CO}_{2}$ release were stimulated by 80 to $90 \%$ and 260 to $270 \%$ for $N$. diversicolor and A. marina, respectively, from basal rates of approximately $30 \mathrm{mmol} \mathrm{m}^{-2}$ $\mathrm{d}^{-1}$. These enhancements in benthic fluxes were due to both increased solute exchange due to macrofauna irrigation and increases in total benthic metabolism. Although the latter was enhanced by 10 to $35 \%$ and 115 to $123 \%$ by N. diversicolor and A. marina, respectively, both species inhibited anaerobic decomposition as indicated by 66 and $42 \%$ lower sulfate reduction rates. Benthic fluxes and basal rates of benthic metabolism (without macrofauna) were 2 to 3 times higher in sediments enriched with organic matter compared to unamended sediments. Similarly, sulfate reduction rates were 3 times higher in enriched sediments. Total benthic metabolism in enriched sediments was stimulated by $N$. diversicolor to a similar extent $(+27$ to $34 \%)$ as in unamended sediments, whereas $A$. marina stimulated total benthic metabolism to a slightly lesser extent ( +43 to $55 \%)$ in enriched sediments than in unamended sediments. $N$. diversicolor had little effect on sulfate reduction $(-4 \%)$ in enriched sediments, while $A$. marina reduced sulfate reduction by $85 \%$ in enriched sediments. Porewater profiles reflected the balance between stimulating effects on sediment decomposition processes and removal of porewater solutes by benthic macrofauna. Porewater and sediment profiles of reduced $\mathrm{S}$ compounds also showed the effects of these polychaetes on sedimentary $S$ cycling, i.e. lower anaerobic decomposition and increased reoxidation of reduced compounds. Both species affected sediment element cycles, stimulating $\mathrm{C}$ cycling and favoring more oxidized species and processes in $\mathrm{S}$ cycling. Furthermore, both species affected the fate and distribution of the metabolites produced from decomposition by enhancing the exchange of solutes across the sediment-water interface and porewater flushing. In general, the biogeochemical impact of $A$. marina was greater than that of $N$. diversicolor.
\end{abstract}

KEY WORDS: Decomposition - Macrofauna - Sediments - Bioturbation - Benthic fluxes - Sulfate reduction - Organic matter

\section{INTRODUCTION}

Burrow dwelling benthic macrofauna play an important role in organic matter decomposition and nutrient cycling processes in sediments (e.g. Rhoads 1974, Aller 1982). Experimental work (e.g. Aller \& Yingst 1985,

\footnotetext{
Present addresses:

- Department of Life Sciences and Chemistry, Roskilde University, PO Box 260, Universitetsvej 1, 4000 Roskilde, Denmark. E-mail: banta@ruc.dk

*Nature Management and Water Environment Division, County of Funen, Ørbœkvej 100, 5220 Odense $\$ \varnothing$, Denmark
}

Kristensen \& Blackburn 1987) has contributed to a basic understanding of macrofaunal effects on sediment processes. The stimulation of total system metabolism and nutrient regeneration by benthic animals has been reported to vary from several hundred percent in many cases (e.g. Kristensen \& Blackburn 1987 , Andersen \& Kristensen 1988, Hansen \& Blackburn 1992, Pelegrí et al. 1994) to only a few percent in some cases (e.g. Aller \& Yingst 1985, Kikuchi 1986, Doering et al. 1987)

While it is generally accepted that benthic macrofauna stimulate overall benthic fluxes, the underlying 
mechanisms for that simulation and which diagenetic processes are specifically affected are less well understood. In most cases the increase in total benthic metabolism results from stimulation of microbial metabolism in excess of macrofauna respiration (e.g. Kristensen \& Blackburn 1987, Hansen \& Blackburn 1992). The partitioning of this stimulated microbial activity into aerobic and anaerobic components is less clear, however. Anaerobic microbes are usually responsible for half or more of the organic matter decomposition in coastal sediments (Mackin \& Swider 1989, Canfield 1993, Jørgensen 1996). Benthic macrofauna are thought to stimulate sediment microbial activity through a variety of direct and indirect mechanisms, such as irrigation, particle mixing, excretion and grazing of microbes (Rhoads 1974, Aller 1982). It is unlikely, however, that aerobic and anaerobic microbes are affected similarly by macrofaunal activities. The oxygenation of sediments by bioturbation and irrigation promotes conditions for aerobic microbes ( $\mathrm{Re}$ traubun et al. 1996) and protozoans (Meyers et al. 1987, Fenchel 1996) and as such must be detrimental to obligate anaerobes. While there have been a number of studies examining the effects of macrofauna on organic matter cycling (e.g. Kikuchi 1986, Kristensen \& Blackburn 1987, Hansen \& Blackburn 1992), sediment and porewater geochemistry (e.g. Aller 1980, Hüttel 1990) and microbial parameters (e.g. Reichardt 1988. Grössmann \& Reichardt 1991), surprisingly few studies have addressed the effects of macrofauna on anaerobic decomposition (e.g. Aller \& Yingst 1978, Hansen et al. 1996, Nielsen 1997).

One of the most important factors for benthic metabolism is the input of degradable organic matter. Total rates as well as the balance between aerobic and anaerobic processes are thus dependent on the concentrations and rate of burial of labile organic matter (Hargrave 1973, Suess 1980, Graf 1992, Blackburn \& Blackburn 1993, Canfield 1993, Jørgensen 1996). It has also been suggested that the effect of benthic macrofauna on sediment metabolism (e.g. the degree of stimulation) is dependent on both the quality and quantity of organic matter in the sediment (Banta 1992, Kristensen et al. 1992).

The purpose of this study was 2-fold. First, we wanted to examine interspecific differences in the effects of benthic macrofauna on aerobic and anaerobic decomposition. Second, we wanted to examine the coupling between organic matter availability, particularly of degradable organic matter, and effects of benthic macrofauna on sediment processes. We used 2 species of common macrofauna in European coastal environments-Nereis diversicolor and Arenicola marina. $N$. diversicolor is well known for its irrigation activities which lead to enhanced flushing and oxy- genation of the upper layers (ca 5 to $10 \mathrm{~cm}$ ) of the sediment (Kristensen 1985). A. marina, on the other hand, is known for its intense bioturbation which includes both particle reworking by head-down deposit feeding (e.g. Rijken 1979, Wheatcroft et al. 1990) and water movement by deep irrigation (>15 cm) (Hüttel 1990, Rasmussen et al. 1998, Riisgård \& Banta 1998). The level and composition of organic matter and macrofauna were manipulated in sediment microcosms where we monitored changes in total benthic metabolism, anaerobic metabolism and sediment parameters for 1 mo.

\section{METHODS}

Sediment microcosms. Sediment microcosms were prepared in 18 PVC core tubes $(35 \mathrm{~cm}$ long and $8 \mathrm{~cm}$ inner diam.) using sandy, organic-poor sediment $(0.06 \%$ particulate organic carbon [POC]) from the Wadden Sea (Königshafen, Island of Sylt, Germany; Station S of Jensen et al. 1996, Kristensen et al. 1998). Sediment was sieved $(1 \mathrm{~mm})$ and frozen to remove macrofauna and meiofauna (Kristensen \& Blackburn 1987). Freezing of sediment was assumed not to significantly affect sediment microbes but this assumption was not tested. It is possible that microbial populations and processes were altered due to the freezing treatment, but it is expected that most sediment processes (aerobic decomposition, sulfate reduction, etc.) returned to normal levels within a number of days after thawing (e.g. Skogland et al. 1988). The return of $\mathrm{CO}_{2}$ release rates after $4 \mathrm{~d}$ to stable, baseline levels in defaunated sediments ( $\mathrm{C}$ microcosms) after initially high release rates (see Fig. 2 later) supports this contention.

After thawing, a portion of sediment was homogenized (mixed by hand) and added to half of the core tubes to a depth of $22 \mathrm{~cm}$ (OM-microcosms). Another portion of sediment was mixed homogeneously with $0.5 \mathrm{~g}$ dried $\left(105^{\circ} \mathrm{C}\right)$ yeast $\mathrm{l}^{-1}$ sediment prior to adding it to the other core tubes (OM+ microcosms). While increasing the organic content of these sediments only slightly $(+0.02 \%$ POC), this addition represented a significant input of labile organic matter $\left(50 \mathrm{~g} \mathrm{C} \mathrm{m}^{-2}\right.$, integrated over the sediment depth of $22 \mathrm{~cm}$ ), corresponding to, for example, 20 to $100 \%$ of the annual benthic primary production typical of sandy, intertidal sediments (e.g. Colijn \& de Jonge 1984).

The next day the sediment was covered with approximately $15 \mathrm{~cm}$ (ca $300 \mathrm{ml}$ ) of seawater (30\%). Microcosms were held in a darkened seawater bath at $15^{\circ} \mathrm{C}$. Each microcosm was connected to a recirculating, flow-through incubation system (Fig. 1) in which the overlying water was exchanged at a rate of approximately $30 \mathrm{ml} \mathrm{min}^{-1}$. Groups of microcosms (3 to 4 repli- 


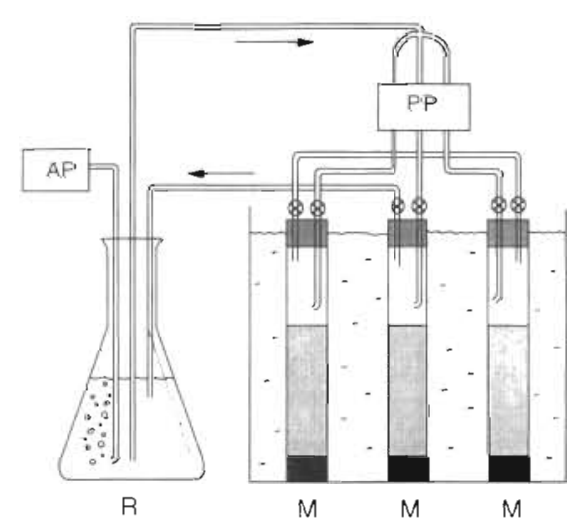

Fig. 1. Experimental setup with a recirculating incubation system containing 3 microcosms (M), representing 1 experimental treatment group. The water reservoir $(R)$ was bubbled with air from an air pump (AP) and continually pumped with a peristaltic pump (PP) into each microcosm, after which it returned to the reservoir

cates for a given experimental treatment) were connected to a common reservoir (4 1) which was bubbled with air to hold the water oxygenated. Reservoirs were renewed with fresh seawater every 1 to 3 d during the 34 d experiment.

After $8 \mathrm{~d}$, polychaetes were added to two-thirds of the microcosms (hereafter referred to as Day 0). Three Nereis diversicolor (140 to $400 \mathrm{mg}$ wet wt) were added to each of $3 \mathrm{OM}$ - microcosms ( $\mathrm{N}$ - microcosms) and 3 $\mathrm{OM}+$ microcosms ( $\mathrm{N}+$ microcosms). Similarly, 3 Arenicola marina of similar size (200 to $400 \mathrm{mg}$ wet wt) were added to each of $3 \mathrm{OM}-$ and $3 \mathrm{OM}+$ microcosms (Aand $\mathrm{A}+$ microcosms, respectively). Animals of this size represent adults for $N$. diversicolor and juveniles for $A$. marina. These additions corresponded to macrofaunal densities of approximately 600 individuals $\mathrm{m}^{-2}$ which are within the range of natural abundances (typically 500 to $5000 \mathrm{~m}^{-2}$ ) for adult $N$. diversicolor (c.g. Heip \& Herman 1979, Vedel \& Riisgård 1993) but represents a high abundance for juvenile A. marina (e.g. Flach \& Beukema 1994). Adult A. marina are much larger (up to $10 \mathrm{~g}$ wet $\mathrm{wt}$ ) and found at much lower densities (25 to $50 \mathrm{~m}^{-2}$ ), but are active much deeper in the sediment than juveniles and would therefore have been difficult to study in the core tubes we used. The remaining $\mathrm{OM}$ - and $\mathrm{OM}+$ microcosms without macrofauna were referred to as $\mathrm{C}-$ and $\mathrm{C}+(4$ of each), respectively.

In addition to these microcosms, 3 cores containing $\mathrm{OM}$ - and 3 cores containing $\mathrm{OM}+$ sediment were prepared using $5 \mathrm{~cm}$ i.d. core tubes. These cores were used to determine initial sediment and porewater conditions at the time macrofauna were added to the microcosms. Furthermore, $3 \mathrm{OM}$ - and $3 \mathrm{OM}+$ cores were prepared in $2.7 \mathrm{~cm}$ i.d. core tubes to measure initial sulfate reduction rates (SRR).
Benthic fluxes. Every 2 to $3 \mathrm{~d}$ throughout the experiment we measured fluxes of $\mathrm{O}_{2}$ and $\mathrm{CO}_{2}$ across the sediment-water interface in the microcosms. Water flow from the reservoirs was stopped and the microcosms were sealed using 3-way valves in the microcosm tops (Fig. 1). The water column was mixed during incubations by ca $1 \mathrm{~cm}$ long magnetic stir bars which. were driven by an electric motor that fit onto the core tops. Over a period of 2 to $11 \mathrm{~h}$ the concentration of $\mathrm{O}_{2}$ was measured repeatedly using a mini $\mathrm{O}_{2}$ electrode (Chemiware A/S, Ábyhøj, Denmark). Between 4 and 8 $\mathrm{O}_{2}$ measurements were made for each microcosm to assure linear changes in concentration.

Duplicate water samples of $13 \mathrm{ml}$ were removed through one of the 3 -way valves repeatedly during a flux incubation to measure benthic $\mathrm{CO}_{2}$ release. The water sampled was replaced simultaneously with reservoir water of a known $\mathrm{CO}_{2}$ content through the other 3 -way valve. $\mathrm{CO}_{2}$ concentrations were corrected for this minor dilution. Microcosms were usually sampled 4 times for $\mathrm{CO}_{2}$ during a flux measurement. Samples were stored in closed plastic syringes (stored submerged in seawater) until the $\mathrm{CO}_{2}$ concentration was measured within a few hours using the flow-injection diffusion cell technique (Hall \& Aller 1992).

Sulfate reduction. SRR were measured both in the initial cores and in all microcosms at the end of the experiment using the ${ }^{35} \mathrm{~S}$ technique (Jørgensen 1978). SRR were measured in the initial cores $(2.7 \mathrm{~cm}$ i.d.) on Day 0. Briefly, cores (OM- or OM+) were injected with $2 \mu \mathrm{l}(70 \mathrm{KBq}) \mathrm{Na}_{2}{ }^{35} \mathrm{SO}_{4}$ at $1 \mathrm{~cm}$ intervals through silicon ports in the side of the core tubes. Cores were incubated for 6 to $8 \mathrm{~h}$ at $15^{\circ} \mathrm{C}$ before being sectioned in 1 and $2 \mathrm{~cm}$ intervals. A 5 or $10 \mathrm{ml}$ sediment sample from each section was placed in equal volumes of $1 \mathrm{M}$ zinc acetate and frozen until later analysis. The radioactivity in both the total reduced sulfur $\left(\mathrm{TR}^{35} \mathrm{~S}\right)$ pool and the remaining ${ }^{35} \mathrm{SO}_{4}$ pool were determined according to the procedure of Fossing \& Jørgensen (1989). The total, non-radioactive TRS pool (mostly FeS and $\mathrm{FeS}_{2}$ ) was determined spectrophotometrically (Cline 1969) as part of the same procedure.

SRR was measured in the experimental microcosms at the end of the experiment (Days 22 to 26). $\mathrm{Na}_{2}{ }^{35} \mathrm{SO}_{4}$ was injected in 6 long vertical lines (evenly spaced in a circle located halfway between the center and the wall of the microcosm) from the sediment surface to the bottom of the microcosm using a Hamilton syringe with a $30 \mathrm{~cm}$ long needle. The depth of the injection, volume of tracer and the rate of delivery were carefully controlled using a micromanipulator. For each line injection $150 \mu \mathrm{l}(1400 \mathrm{KBq})$ of carrier free $\mathrm{Na}_{2}{ }^{35} \mathrm{SO}_{4}$ in a $550 \mathrm{mM} \mathrm{NaCl}$ solution was distributed evenly over a depth of $20 \mathrm{~cm}$. Microcosms were incubated for $12 \mathrm{~h}$ at $15^{\circ} \mathrm{C}$. After incubation, microcosms were sectioned in 

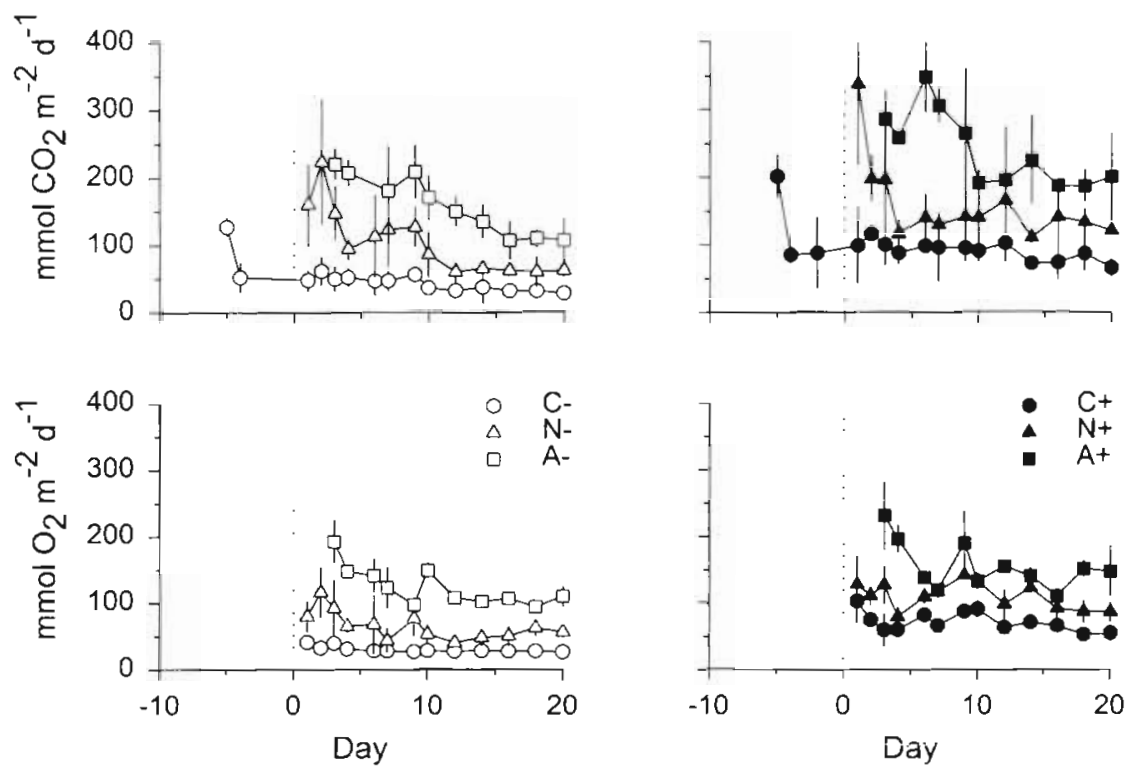

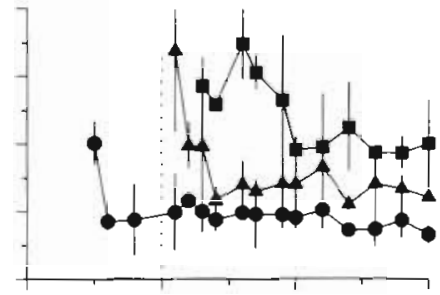

Fig. 2. Benthic $\mathrm{CO}_{2}$ release (top) and $\mathrm{O}_{2}$ uptake rates (bottom) for the OM(left) and OM+ (right) microcosms during the course of the experiment. Note that macrofauna were added on Day 0 as indicated by the dotted line. Values are mean \pm standard error for 2 to 4 microcosms. $\mathrm{O}_{2}$ fluxes were not measured until Day 1 due to problems with the electrodo
1 to $2 \mathrm{~cm}$ intervals. The sediment sections were processed and analyzed in a similar fashion to the initial cores, except that the microcosms were sectioned in a glove-bag under an $\mathrm{N}_{2}$ atmosphere to allow measurement of dissolved sulfides (see below).

Sediment and porewater parameters. Several sediment and porewater parameters were measured for the initial cores (Day 0) and the experimental microcosms at the end of the experiment. While in the glovebag, sediment from each depth interval was placed in split-centrifuge tubes containing a GF/C glass fiber filter. Porewater was extracted from sediment subsamples by centrifugation at $1500 \mathrm{rpm}(400 \times \mathrm{g})$ for $5 \mathrm{~min}$ and sampled for $\mathrm{TCO}_{2}, \mathrm{SO}_{4}{ }^{2-}$ and dissolved sulfides (DS). $\mathrm{TCO}_{2}$ was determined as described above (Hall \& Aller 1992) after the precipitation of dissolved sulfides using $\mathrm{HgCl}_{2}$. Sulfate was measured by ion liquid chromatography and UV-detection using a Kontron Ion Liquid Chromatograph with $2.5 \mathrm{mM}$ potassium hydrogen phthalate ( $\mathrm{pH}=4.5$ ) as eluent. DS were precipitated with $1 \mathrm{M}$ zinc acetate $\left(100 \mu \mathrm{ml}^{-1}\right.$ porewater $)$ and analyzed according to Cline (1969).

Samples of sediment were processed for porosity and density. Wet and dry densities $\left(130^{\circ} \mathrm{C}\right)$ were measured for known volumes of sediment, allowing us to calculate porosity. Dried sediment samples were stored for later analysis of organic content as loss on ignition (LOI) and POC. For LOI, sediments were combusted at $520^{\circ} \mathrm{C}$ for $6 \mathrm{~h}$. POC was measured on the dried sediments using a Carlo Erba CHNS analyzer (model 1100EA) according to Kristensen \& Andersen (1987).

Polychaete respiration. Respiration rates of Nereis diversicolor and Arenicola marina that had been reared for $2 \mathrm{wk}$ in $\mathrm{OM}$ - and OM+ sediments were measured both as $\mathrm{O}_{2}$ uptake and $\mathrm{CO}_{2}$ release. Worms were allowed to clear their guts overnight before initiating measurements. Individual worms were placed in appropriately sized glass tubes which allowed normal, undulatory movements while ventilating. Kristensen (1981) has shown that this is important for obtaining realistic respiration rates for Nereis species. Worms (inside a glass tube) were sealed in 10 to $30 \mathrm{ml}$ test tubes for 0.5 to $3 \mathrm{~h}$. Initial $\mathrm{O}_{2}$ and $\mathrm{CO}_{2}$ concentrations were determined in the water used to fill the test tubes. Final $\mathrm{O}_{2}$ and $\mathrm{CO}_{2}$ concentrations in the test tubes were measured after the incubation. Oxygen was analyzed by the Winkler technique and $\mathrm{CO}_{2}$ was analyzed by flow-injection as above.

Statistical analysis. A 2-way factorial analysis of variance (ANOVA) was used to test the main effects of added organic matter (2 OM levels: natural or amended) and the different macrofauna treatments ( 3 groups: control, Nereis diversicolor and Arenicola marina) as well as the interaction between these 2 factors on various fluxes and rates. Similarly, effects on sediment organic content (LOI) were tested with a similar 2-factor ANOVA design with initial conditions (Init.) included as an extra group in the macrofauna treatment factor.

The ANOVA assumptions that the data were normally distributed with homogeneous variance were tested and the data were log transformed where necessary. Significant effects found in the ANOVA analysis, both main effects and interactions, were further investigated using Tukey or Bonferroni post hoc multiple comparisons between treatment means (Milliken \& Johnson 1984, Zar 1984). 


\section{RESULTS}

\section{Benthic fluxes}

Except for initial high rates of $\mathrm{CO}_{2}$ release, presumably resulting from disturbances associated with the establishment of the microcosm, benthic fluxes of $\mathrm{O}_{2}$ and $\mathrm{CO}_{2}$ (Fig, 2) in the $\mathrm{C}$ - and $\mathrm{C}+$ microcosms (no macrofauna) were quite constant throughout most of the experiment. Rates of $\mathrm{O}_{2}$ uptake and $\mathrm{CO}_{2}$ release were always about 2 times higher in the organicenriched microcosms $(\mathrm{C}+)$ than in unamended microcosms $(\mathrm{C}-)$ (p $\leq 0.000001)$.

The addition of macrofauna led to dramatic increases in both $\mathrm{O}_{2}$ uptake and $\mathrm{CO}_{2}$ release (Fig. 2), although the pattern and duration of the responses were different for Nereis diversicolor and Arenicola marina. The addition of $N$. diversicolor generally resulted in initially high, but rapidly decreasing fluxes. Oxygen uptake increased instantly by a factor of 2 to 3 after the addition of $N$. diversicolor to $\mathrm{N}$ - microcosms (Fig. 2, bottom left) but after $10 \mathrm{~d}$ the rates fell to levels that were 46 to $125 \%$ greater than in $\mathrm{C}$ - microcosms. In $\mathrm{N}+$ microcosms, on the other hand, the addition of $N$. diversicolor caused no initial peak in $\mathrm{O}_{2}$ uptake, but the rates were 42 to $159 \%$ greater than in C+ microcosms throughout the experiment (Fig. 2, bottom right). Oxygen uptake at the end of the experiment (Day 12 to end) was 89 and $72 \%$ higher in $\mathrm{N}$ - and $\mathrm{N}+$ microcosms than in $\mathrm{C}$ - and $\mathrm{C}+$ microcosms, respectively (Table $1, \mathrm{C}$ vs $\mathrm{N}: \mathrm{p} \leq$ 0.0002 ). The release of $\mathrm{CO}_{2}$ from the sediments behaved similarly to $\mathrm{O}_{2}$ uptake, although $\mathrm{N}+$ microcosms also showed a dramatic initial peak in release (Fig. 2, top). At the end of the experiment $\mathrm{CO}_{2}$ release rates were 72 to $78 \%$ greater with $N$. diversicolor present (C vs $N: p \leq 0.0002$ ) although the effect of $N$. diversicolor was less significant in $\mathrm{OM}$ - sediments ( $\mathrm{C}-\mathrm{vs} \mathrm{N}$-: $\mathrm{p} \leq 0.09$ and $\mathrm{C}+\mathrm{vs} \mathrm{N}+\mathrm{p} \leq 0.0002$ ).

The addition of Arenicola marina led to larger and more sustained increases in benthic $\mathrm{O}_{2}$ uptake and $\mathrm{CO}_{2}$ release (Fig. 2). Oxygen uptake increased by a factor of 4 for A- microcosms and a factor of 2.5 for A+ microcosms immediately after the addition of $A$. marina relative to $\mathrm{C}-$ and $\mathrm{C}+$ microcosms, respectively. Oxygen uptake rates in both $\mathrm{A}$ treatments fell gradually during the remainder of the experiment, but remained above the level of $\mathrm{N}$ microcosms. Oxygen uptake rates in $\mathrm{A}$ - and $\mathrm{A}+$ microcosms at the end of the experiment were high, still being 4 and 2.5 times greater than their respective control microcosms (C vs A: $p \leq 0.0002$ ). The release rate of $\mathrm{CO}_{2}$ was similarly affected by adding $A$. marina as was $\mathrm{O}_{2}$ uptake (Fig. 2, top; $\mathrm{C}-$ vs $\mathrm{A}-\mathrm{p} \mathrm{p} \leq 0.00001 ; \mathrm{C}+$ vs $\mathrm{A}+: \mathrm{p} \leq 0.00001)$, although $\mathrm{CO}_{2}$ release rates for all treatments became more alike at the end of the experiment.

\section{Polychaete respiration}

The expected log-log allometric relationships between polychaete respiration and size were observed for both Nereis diversicolor and Arenicola marina (Table 2). When considering a 'typical' polychaete of $300 \mathrm{mg}$ (wet weight) in our microcosms, respiration rates for polychaetes living in organically enriched sediments were slightly higher than in unamended sediments (Table 2). Respiratory quotients $\left(\mathrm{CO}_{2}\right.$ release $/ \mathrm{O}_{2}$ uptakel estimated from these allometric relations for a typical polychaete (300 mg) were 1.3 for $N$. diversicolor and 1.4 for $A$. marina.

Table 1. Benthic fluxes $\left(\mathrm{O}_{2}\right.$ and $\left.\mathrm{CO}_{2}\right)$ at the end of the experiment. Positive values indicate fluxes out of the sediment while negative values are fluxes into the sediment. Results are mean \pm standard error for 2 to 4 microcosms from Day 12 to the end of the experiment. The percent values for $\mathrm{N}$ and $\mathrm{A}$ microcosms represent the changes relative to $\mathrm{C}$ - or $\mathrm{C}+$ flux rates

\begin{tabular}{|c|c|c|}
\hline \multirow[t]{2}{*}{ Treatment } & \multicolumn{2}{|c|}{$\mathrm{mmol} \mathrm{m} \mathrm{m}^{-2} \mathrm{~d}^{-1}$} \\
\hline & $\mathrm{O}_{2}$ & $\mathrm{CO}_{2}$ \\
\hline C- & $-27.9 \pm 1.2$ & $33.8 \pm 2.8$ \\
\hline $\mathrm{C}+$ & $-57.4 \pm 6.0$ & $77.5 \pm 5.9$ \\
\hline N- & $-52.8 \pm 7.7(+89 \%)$ & $60.0 \pm 6.9(+78 \%)$ \\
\hline$N+$ & $-98.6 \pm 6.9(+72 \%)$ & $133.5 \pm 12.0(+72 \%)$ \\
\hline A- & $-103.4 \pm 0.3(+271 \%\}$ & $121.0 \pm 3.4+(258 \%)$ \\
\hline$A+$ & $-138.4 \pm 3.4(+141 \%)$ & $199.5 \pm 5.0(+157 \%)$ \\
\hline
\end{tabular}

Table 2. Coefficients for allometric relationships for polychaete respiration rates for worms reared in organic-poor sediments either with (OM+) or without (OM-) organic matter additions. The coefficients $a$ and $b$ are from the allometric equation $V=a M^{b}$, where $V$ is respiration of either $\mathrm{O}_{2}$ or $\mathrm{CO}_{2}$ ( $\mu$ mol $h^{-1}$ ) and $M$ is the wet weight $(g)$ of the polychaete. The coefficient of determination, $\mathrm{R}^{2}$, for each curve was based on a linear regression of $\log (V)$ vs $\log (M)$. Respiration of a 'typical' polychaete of $300 \mathrm{mg}$ is given as $V_{300 \mathrm{mg}}$

\begin{tabular}{|c|c|c|c|c|c|}
\hline Species & $\begin{array}{l}\text { OM } \\
\text { level }\end{array}$ & $a$ & $b$ & $\begin{array}{l}\mathrm{R}^{2} \\
(\%)\end{array}$ & $\begin{array}{c}V_{300 m g} \\
\left(\mu \mathrm{mol} \mathrm{h}{ }^{-1}\right)\end{array}$ \\
\hline \multicolumn{6}{|l|}{$\mathrm{O}_{2}$} \\
\hline & - & 1.54 & 0.51 & 97 & 0.83 \\
\hline & + & 2.76 & 0.85 & 96 & 0.99 \\
\hline \multicolumn{6}{|c|}{ Arenicola marina } \\
\hline & - & 1.97 & 0.75 & 95 & 0.80 \\
\hline & + & 2.39 & 0.66 & 89 & 1.08 \\
\hline \multicolumn{6}{|c|}{$\begin{array}{l}\mathrm{CO}_{2} \\
\text { Nereis diversicolor }\end{array}$} \\
\hline & - & 2.86 & 0.79 & 91 & 1.10 \\
\hline & + & 4.39 & 1.02 & 99.6 & 1.28 \\
\hline \multicolumn{6}{|c|}{ Arenicola marina } \\
\hline & - & 2.65 & 0.73 & 92 & 1.10 \\
\hline & + & 2.93 & 0.56 & 95 & 1.49 \\
\hline
\end{tabular}




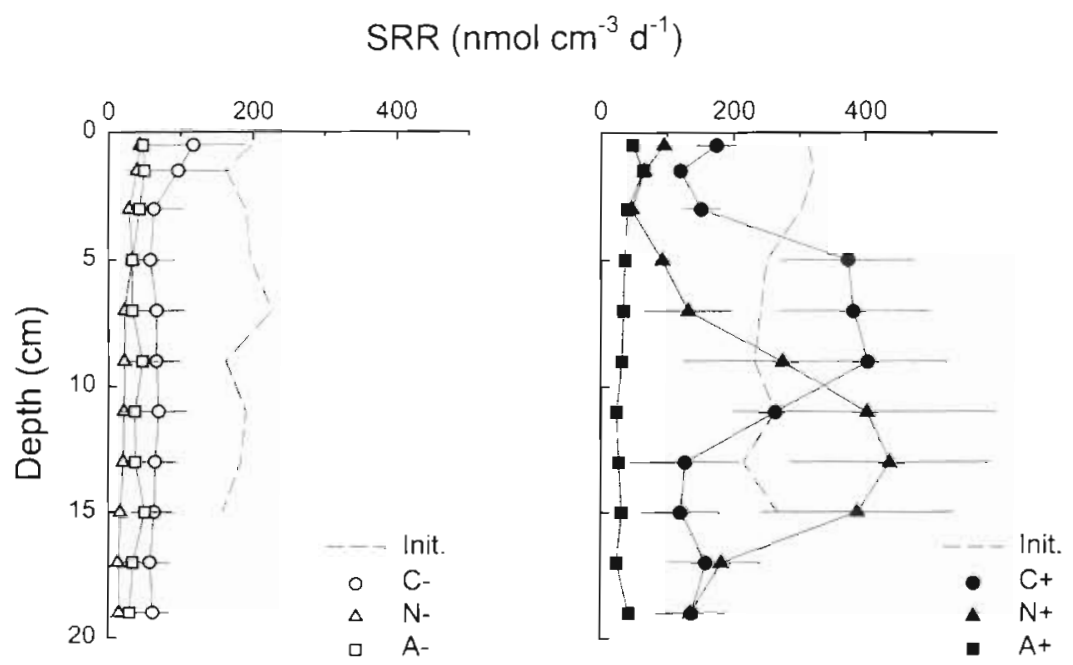

Fig. 3. Profiles of sulfate reduction rates ( $S R R$ ) for the $O M-$ (left) and $O M+$ (right) initial sediments (Day ()) and microcosms at the end of the experimeut. Values are mean \pm standard error for 2 to 4 cores or microcosms

\section{Sulfate reduction}

Initial (Day 0) SRR were constant with depth at 150 to $200 \mathrm{nmol} \mathrm{S} \mathrm{cm} \mathrm{cm}^{-3} \mathrm{~d}^{-1}$ for OM- sediments and 250 to $300 \mathrm{nmol} \mathrm{S} \mathrm{cm} \mathrm{c}^{-3} \mathrm{~d}^{-1}$ for OM+ sediments (Fig. 3). At the end of the experiment, however, SRR differed greatly between OM- and OM+ microcosms. All OM-microcosms had low SRR, less than $150 \mathrm{nmol} \mathrm{S} \mathrm{cm} \mathrm{cm}^{-3}$ (Fig. 3, left), with slightly higher rates in $\mathrm{C}$ - microcosms than in either $\mathrm{N}$ - or $\mathrm{A}$ - microcosms. High rates of sulfate reduction (averaging up to $400 \mathrm{nmol} \mathrm{S} \mathrm{cm} \mathrm{cm}^{-3}$ $\mathrm{d}^{-1}$ ) were measured in both $\mathrm{C}+$ and $\mathrm{N}+$ microcosms (Fig. 3, right), but at different depths. Sulfate reduction rates peaked at 5 to $10 \mathrm{~cm}$ in $\mathrm{C}+$ microcosms, and at 12 to $15 \mathrm{~cm}$ in $\mathrm{N}+$ microcosms. Sulfate reduction was limited by $\mathrm{SO}_{4}{ }^{2-}$ at depth in $\mathrm{C}+$ microcosms (see later). A+ microcosms had low SRR, similar to $\mathrm{N}$ and $\mathrm{A}-$ microcosms, at all sediment depths.

\section{Sediments}

Concentrations of $\mathrm{POC}$ in the initial OMand $O M+$ sediments were very low for both treatments: $0.058 \pm 0.005 \%$ for $\mathrm{OM}$ - sediment and $0.065 \pm 0.017 \%$ for $\mathrm{OM}+$ sediment. There were no differences in LOI between organic matter treatments $(\mathrm{p} \leq$ 0.54). All microcosms had significantly lower organic content (LOI) at the end of the experiment (Fig. 4) compared to initial conditions (Initials vs $\mathrm{C}, \mathrm{N}$ and $\mathrm{A}$ micro- cosms: $p \leq 0.002,0.001$ and 0.009 , respectively). The organic content in $\mathrm{C}, \mathrm{N}$ and $\mathrm{A}$ microcosms did not differ, however ( $\mathrm{C}$ vs $\mathrm{N}: \mathrm{p} \leq 0.96 ; \mathrm{C}$ vs $\mathrm{A}: \mathrm{p} \leq$ 0.98 ; $N$ vs $A: p \leq 0.85$ ). Organic content decreased slightly with depth in all microcosms except in A microcosms, where there was a slight increase between 5 and $10 \mathrm{~cm}$.

The initial concentrations of TRS ranged from 2 to $4 \mu \mathrm{mol} \mathrm{S} \mathrm{cm} \mathrm{cm}^{-3}$ in $\mathrm{OM}-$ and OM+ microcosms (Fig. 5). By the end of the experiment, TRS concentrations had increased in control sediments (Fig. 5), with the greatest increase in $\mathrm{C}+$ microcosms (4 to $5 \mu \mathrm{mol} \mathrm{S} \mathrm{cm}^{-3}$ ) compared to $\mathrm{C}$ microcosms ( 3 to $4 \mu \mathrm{mol} \mathrm{S} \mathrm{cm}^{-3}$ ). The effect of macrofauna on TRS concentrations depended on the level of organic matter. Generally, OMmicrocosms lost TRS when macrofauna were present (Fig. 5, left), especially for A- microcosms at depths greater than $10 \mathrm{~cm}\left(1\right.$ to $\left.2 \mu \mathrm{mol} \mathrm{S} \mathrm{cm} \mathrm{cm}^{-3}\right)$. With added organic matter TRS mostly accumulated, even when macrofauna were present (Fig. 5, right). In $\mathrm{N}+$ microcosms, TRS accumulation below $10 \mathrm{~cm}$ was similar to that in $\mathrm{C}+$ microcosms. In $\mathrm{A}+$ microcosms, TRS followed the same pattern as $\mathrm{N}+$ microcosms at intermediate depths ( 5 to $8 \mathrm{~cm}$ ), but was reduced by half below $10 \mathrm{~cm}$ in the sediments. It was evident, especially in OM+ microcosms, that Nereis diversicolor exerted the greatest effect in the upper layers

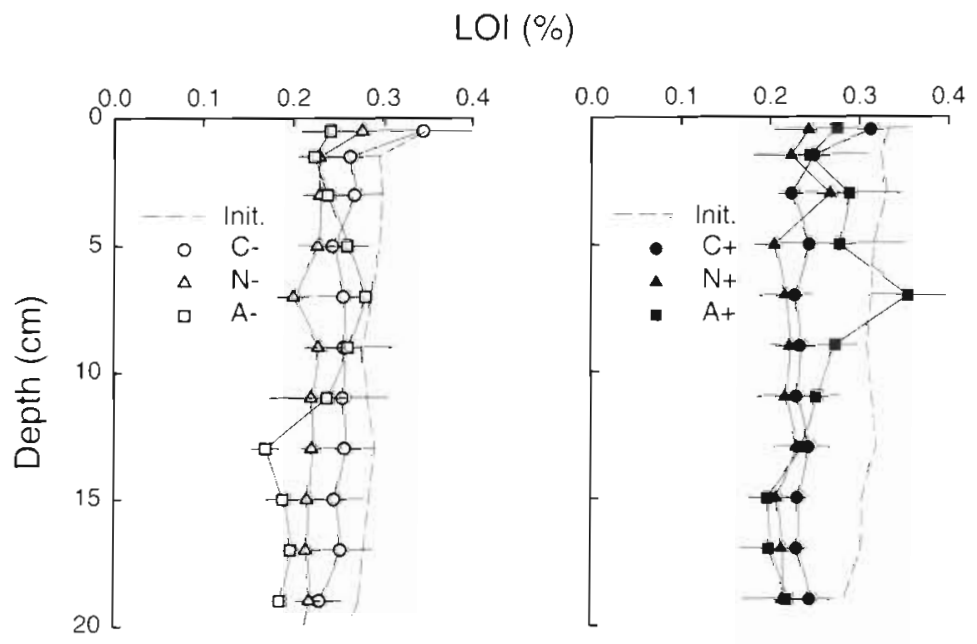

Fig. 4. Profiles of organic content (LOI) for the OM- (left) and OM+ (right) initial sediments (Day 0 ) and microcosms at the end of the experiment. Values are mean \pm standard error. for 2 to 4 cores or microcosms 


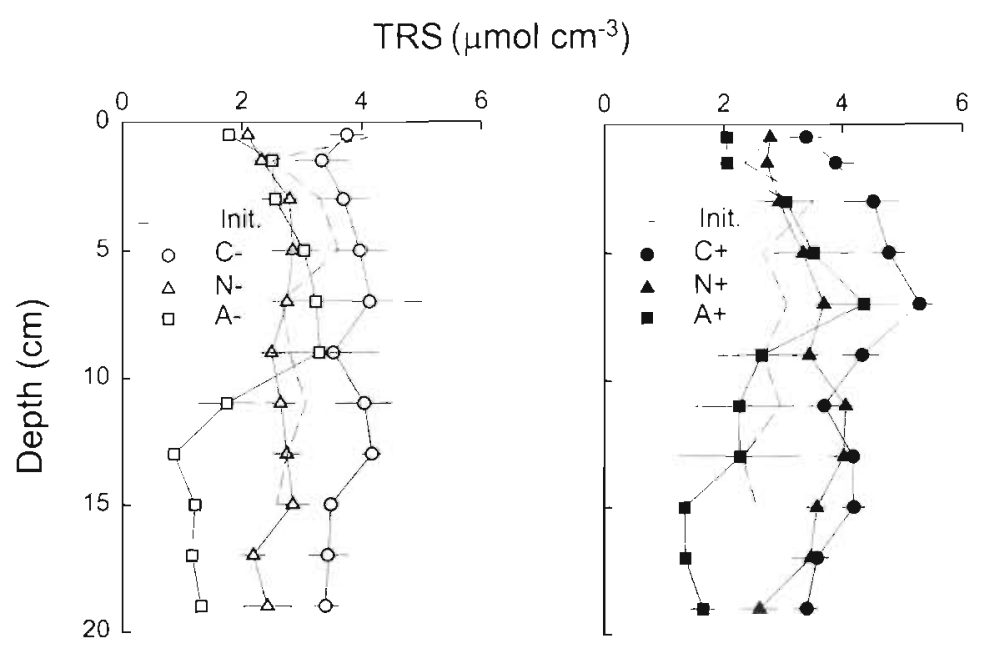

Fig. 5. Profiles of total reduced inorganic sulfur (TRS) for the OM- (left) and $\mathrm{OM}+$ (right) initial sediments (Day 0 ) and microcosms at the end of the experiment. Values are mean \pm standard error for 2 to 4 cores or microcosms

of the sediment while Arenicola marina mostly affected the deeper layers.

Sediment porosities were low (15 to $30 \%$ ) and similar for all treatment groups (data not shown).

\section{Porewater}

Initial profiles of porewater $\mathrm{TCO}_{2}$ were similar for OM- and OM+ sediments (Fig. 6), although slightly higher in $\mathrm{OM}$ - compared to $\mathrm{OM}+$ sediments. Concentrations of $\mathrm{TCO}_{2}$ had stabilized below $4 \mathrm{~cm}$ at 13 to $15 \mathrm{mM}$ for $\mathrm{OM}$ - and 9 to $12 \mathrm{mM}$ for $\mathrm{OM}+$ sediments at the start of the experiment, $8 \mathrm{~d}$ after establishing the microcosms. At the end, porewater concentrations of $\mathrm{TCO}_{2}$ were 2 to 3 times higher than initial concentrations, with concentrations of 30 to $40 \mathrm{mM}$ in $\mathrm{C}-$ microcosms and 15 to $80 \mathrm{mM}$ in $\mathrm{C}+$ microcosms. The increase in $\mathrm{TCO}_{2}$ at depth (where there had not been sufficient time for removal of $\mathrm{CO}_{2}$ by molecular diffusion) allowed us to estimate $\mathrm{CO}_{2}$ production rates of $428 \mathrm{nmol} \mathrm{C} \mathrm{cm} \mathrm{cm}^{-3} \mathrm{~d}^{-1}$ for $\mathrm{C}$ - sediments and $687 \mathrm{nmol} \mathrm{C} \mathrm{cm} \mathrm{cm}^{-3} \mathrm{~d}^{-1}$ for $\mathrm{C}+$ sediments. Assuming the same production rates for the top $20 \mathrm{~cm}$ of sediment, this corresponds to areal production rates of 85 and $137 \mathrm{mmol} \mathrm{C} \mathrm{m} \mathrm{m}^{-2} \mathrm{~d}^{-1}$, respectively.

In contrast to $\mathrm{C}$ microcosms, porewater $\mathrm{TCO}_{2}$ concentrations decreased dramatically when Arenicola marina were present, to $4-6 \mathrm{mM}$ in A- and 3-4 mM in A+ microcosms. The results for the $\mathrm{N}$ microcosms were variable but tended to be intermediate between the $\mathrm{C}$ and $\mathrm{A}$ microcosms. $\mathrm{N}+$ microcosms had high $\mathrm{TCO}_{2}$ concentrations ( 60 to $80 \mathrm{mM}$ ) at depth, but a distinct zone in the upper 4 to $5 \mathrm{~cm}$ of the sediment had a concave profile indicating either consumption (uptake) or removal (flushing) of $\mathrm{TCO}_{2}$. The pattern was similar for $\mathrm{N}$ - microcosms, except that the upper concave portion was extended to $15 \mathrm{~cm}$ depth.

Initial concentrations of $\mathrm{SO}_{4}{ }^{2}$ in the porewater were 28 to $29 \mathrm{mM}$ at the sediment surface and 22 to $23 \mathrm{mM}$ at depth (Fig. 7). At the end of the experiment, $\mathrm{C}$ and $\mathrm{N}$ microcosms showed various degrees of increased $\mathrm{SO}_{4}{ }^{2-}$ depletion, while A microcosms had constant $\mathrm{SO}_{4}{ }^{2-}$ concentrations (25 to $29 \mathrm{mM}$ ) at all depths. The depletion was most severe in $\mathrm{C}+$ and $\mathrm{N}+$ microcosms (Fig. 7, right), where concentrations were lower than $5 \mathrm{mM}$ below $10 \mathrm{~cm}$. Depletion was less severe, but still evident in $\mathrm{C}$ - and $\mathrm{N}$ - microcosms (Fig. 7, left). Rates of $\mathrm{SO}_{4}{ }^{2-}$ depletion corresponded to $\mathrm{SRR}$ of 180 and $360 \mathrm{nmol} \mathrm{S} \mathrm{cm}^{-3} \mathrm{~d}^{-1}$ or 36 and $72 \mathrm{mmol} \mathrm{S} \mathrm{m}{ }^{-2}$ $\mathrm{d}^{-1}$ in $\mathrm{C}$ - and $\mathrm{C}+$ microcosms, respectively.

DS concentrations were extremely variable at the end of the experiment (Fig. 8). Control microcosms had high DS concentrations of up to $2-4 \mathrm{mM}$. Among the macrofauna treatments, only $\mathrm{N}+$ microcosms had high DS concentrations at depth $(>5 \mathrm{~cm})$. All other faunated microcosms had DS concentrations of a few hundred $\mu \mathrm{M}(\mathrm{N}-)$ or barely detectable levels (a few $\mu \mathrm{M}, \mathrm{A}-$ and $\mathrm{A}+$ ).

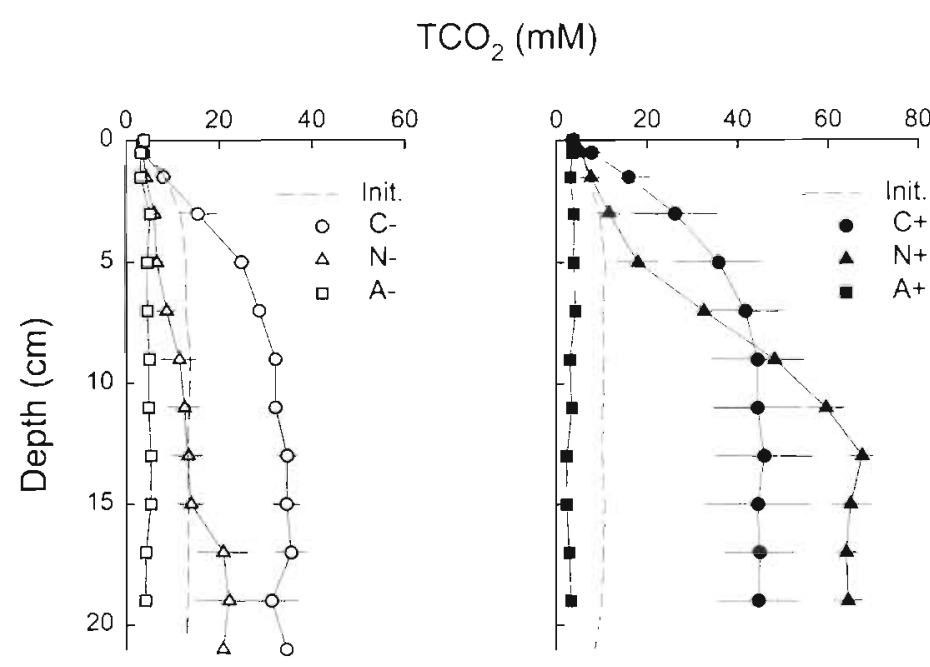

Fig. 6. Porewater profiles of dissolved inorganic carbon $\left(\mathrm{TCO}_{2}\right)$ for the OM- (left) and OM+ (right) initial cores (Day 0) and microcosms at the end of the experiment. Values are mean \pm standard error for 2 to 4 cores or microcosms 


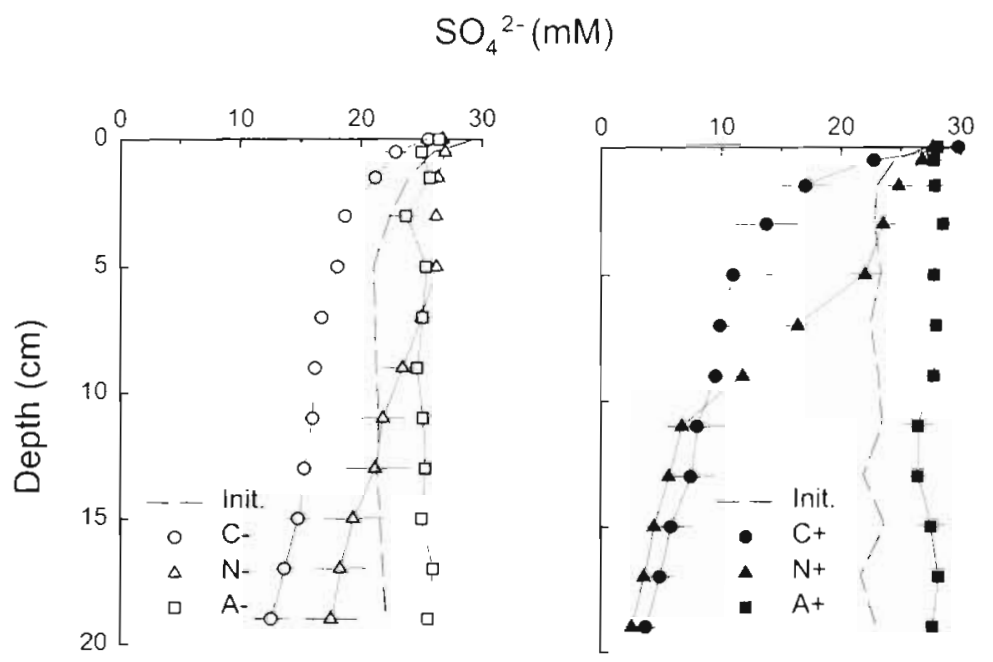

Fig. 7. Porewater profiles of $\mathrm{SO}_{4}{ }^{2-}$ for the $\mathrm{OM}-$ (left) and $\mathrm{OM}+$ (right) microcosms at the end of the experiment. Vaiues are mean \pm sidnulard error for 2 to 4 cores or microcosms

cies of macrofauna were consistent with such porewater flushing effects.

Stimulation of benthic metabolism by macrofauna is expected to be less instantaneous and start more gradually. Microbial communities will respond to changes in sediment conditions (Meyer-Reil 1983), presumably also those caused by macrofauna, but such a response would have different temporal characteristics than porewater flushing. Effects of macrofauna on sediment metabolism would be expected to be longlasting, in contrast to effects due to porewater flushing. Both benthic $\mathrm{O}_{2}$ uptake and $\mathrm{CO}_{2}$ release were stimulated throughout the course of this experiment, indicating that these 2 macrofauna species also had longlasting effects on benthic metabolism.

\section{Evidence from porewater profiles}

\section{DISCUSSION}

\section{Effects of macrofauna on benthic fluxes}

Both species of macrofauna had significant and longlasting stimulative effects on benthic fluxes. In general, Nereis diversicolor enhanced fluxes ( +72 to $82 \%$ ), but to a lesser extent than Arenicola marina $(+141$ to $271 \%$ ) (Table 1). Similar levels of enhancement of benthic fluxes by nereid worms have been observed by others (Kikuchi 1986, Kristensen \& Blackburn 1987. Andersen \& Kristensen 1988, Pelegrí \& Blackburn 1995). There is surprisingly little reported in the literature about the effects of arenicolid worms on fluxes, although substantial effects of $A$. marina on porewater constituents (Hüttel 1990) and sediment microbes (Reichardt 1988, Grössman \& Reichardt 1991) have been documented.

Benthic macrofauna affect benthic fluxes by enhancing the exchange of dissolved materials between sediment porewaters and the overlying water (porewater flushing) and by altering rates of benthic metabolism. The timing and duration of these 2 effects can be expected to differ, however. Flushing of solutes from porewaters should be more or less immediate after the colonization of a previously defaunated sediment (Kristensen \& Blackburn 1987. Hansen \& Blackburn 1992, Hansen \& Kristensen 1997). The immediate increases in benthic $\mathrm{CO}_{2}$ release after adding both spe-
The concentrations of porewater solutes in faunated sediments indicated that the enhanced exchange of materials between sediments and overlying water due to irrigation was most pronounced for Arenicola marina. A. marina is a deep burrowing head-down deposit feeder with moderately high irrigation rates (10 to $60 \mathrm{ml} \mathrm{g}^{-1} \mathrm{~h}^{-1}$ ) (Riisgård et al. 1996, Rasmussen et al. 1998). An important feature of A. marina's irrigation is that the water pumped down into the burrow is injected into the sediments at the feeding pocket and returns to the surface via advective transport along the path of least resistance, usually through the feeding

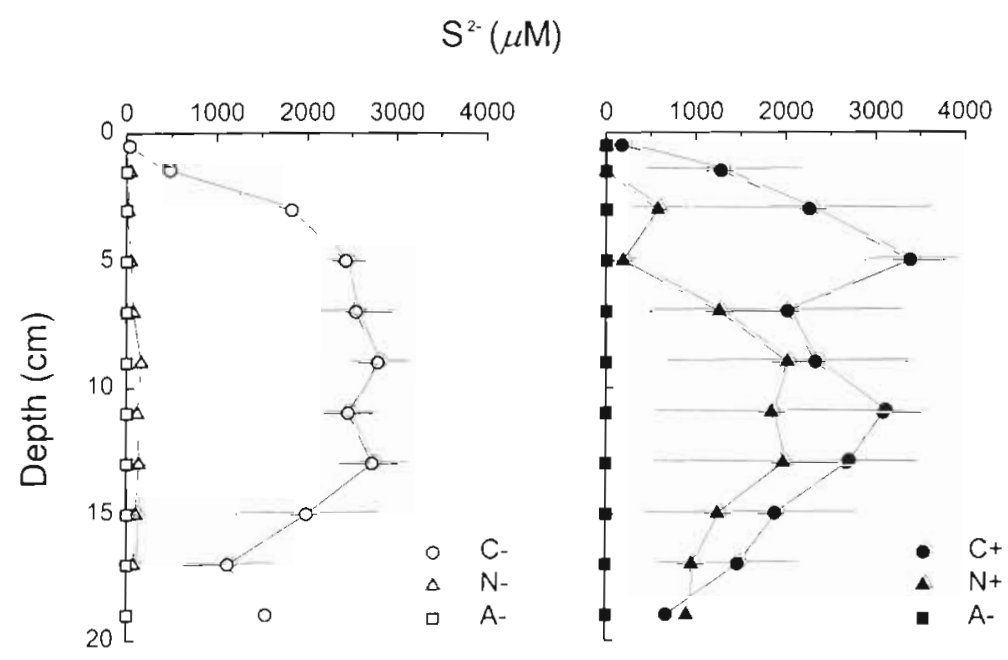

Fig. 8. Porewater profiles of dissolved sulfide, $\mathrm{S}^{2-}$, for the $\mathrm{OM}-$ (left) and $\mathrm{OM}+$ (right) microcosms at the end of the experiment. Values are mean \pm standard error for 2 to 4 cores or microcosms 

is the integrated respiration by the experimental microcosms over the $20 \mathrm{~d}$ period (Fig. 2). $\triangle$ TRS was calculated as the change in TRS concentrations (Fig. 5) in the top $20 \mathrm{~cm}$ from initial concentrations on Day 0 to the end of the experiment. Positive values indicate an accumulation of TRS during the experiment. DS pool is the depth-integrated (to $20 \mathrm{~cm}$ ) DS concentrations (Fig. 8) at the end of the experiment. Total $\mathrm{O}_{2}$ demand was calculated as the sum of benthic respiration, $\triangle$ TRS and DS pool after converting $\mathrm{S}$ to $\mathrm{O}_{2}$ equivalents (1:2). Values are given as mean \pm standard error for 2 to 4 replicate microcosms. ANOVA of untransformed data indicated that there were significant differences in total $\mathrm{O}_{2}$ demand due to the macrofauna treatment ( $\mathrm{p} \leq 0.001)$ and organic matter level $(p \leq 0.001)$, but that the interaction of these 2 factors was not significant $\left(\mathrm{p} \leq 0.36\right.$ ). Benthic $\mathrm{O}_{2}$ uptake is possibly underestimated for A microcosms because of missing measurements on Days 1 to 3

\begin{tabular}{|ccccc|}
\hline Treatment & $\begin{array}{c}\text { Benthic } \\
\mathrm{O}_{2} \text { uptake } \\
\left(\mathrm{mmol} \mathrm{O}_{2} \mathrm{~m}^{-2}\right)\end{array}$ & $\begin{array}{c}\mathrm{TRS} \\
\left(\mathrm{mmol} \mathrm{S} \mathrm{m}^{-2}\right)\end{array}$ & $\begin{array}{c}\mathrm{DS} \\
\text { pool } \\
\left(\mathrm{mmol} \mathrm{S} \mathrm{m}^{-2}\right)\end{array}$ & $\begin{array}{c}\text { Total } \mathrm{O}_{2} \\
\text { demand } \\
\left(\mathrm{mmol} \mathrm{O}_{2} \mathrm{~m}^{-2}\right)\end{array}$ \\
\hline $\mathrm{C}-$ & $560 \pm 15$ & $136 \pm 53$ & $89 \pm 10$ & $997 \pm 120$ \\
$\mathrm{~N}-$ & $1174 \pm 176$ & $-42 \pm 31$ & $3 \pm 1$ & $1097 \pm 180$ \\
$\mathrm{~A}-$ & $2405 \pm 61$ & $-129 \pm 42$ & $0.1 \pm 0.03$ & $2222 \pm 60$ \\
$\mathrm{C}+$ & $1191 \pm 136$ & $229 \pm 39$ & $122 \pm 10$ & $1871 \pm 325$ \\
$\mathrm{~N}_{+}$ & $2060 \pm 91$ & $102 \pm 7$ & $60 \pm 29$ & $2384 \pm 151$ \\
$\mathrm{~A}+$ & $3004 \pm 143$ & $-48 \pm 30$ & $0.1 \pm 0.01$ & $2908 \pm 182$ \\
\hline
\end{tabular}

Table 3. Budget of Total $\mathrm{O}_{2}$ demand for Days 1 to 20. Benthic $\mathrm{O}_{2}$ uptake

in contrast to A microcosms. Studies of $N$. diversicolor (Kristensen \& Hansen 1999) and of a related species, $N$. virens (Henriksen et al. 1983, Kristensen \& Blackburn 1987), also indicated that flushing primarily occurs in the upper sediment layers. High concentrations of metabolites accumulated in the deeper layers of $\mathrm{N}$ microcosms where $N$. diversicolor irrigation had little effect.

\section{Evidence from total benthic metabolism}

Fluxes of materials across the sediment-water interface can be used as a net measure of all processes occurring in the sediment under the assumption that all sediment processes and porewater profiles have reached steadystate (Berner 1980). While benthic flux rates (Figs. 2 \& 3) were stable at the end of the experiment, suggesting that 'local' steady-state conditions were being approached, true steady state could not have been reached given the relative short time of the experi- funnel (Rijken 1979, Hüttel 1990, Timmermann, Christensen \& Banta unpubl.). The irrigation activities of $A$. marina were so intense that the porewater profiles in the present experiment were completely flat throughout the entire sediment profile, despite high rates of production or consumption of metabolites (based on benthic metabolism rates). Others (e.g. Hüttel 1990) have also observed that $A$. marina is capable of flushing sediment porewaters to significant depths.

Irrigation effects by Nereis diversicolor were more moderate and balanced with benthic metabolism. $N$. diversicolor is a tube-dwelling polychaete that irrigates more intensely (250 to $700 \mathrm{ml} \mathrm{g}^{-1} \mathrm{~h}^{-1}$ ) (Kristensen 1983) than Arenicola marina. Irrigation rates are even higher $(1000$ to $1900 \mathrm{ml}$ $\mathrm{g}^{-1} \mathrm{~h}^{-1}$ ) when $N$. diversicolor is filter-feeding (Riisgård 1991), although such high irrigation rates were not likely in our experiment because there were no algae in the water. Irrigation by $N$. diversicolor results in a rapid transport of water though the worm's tube and back to the overlying water with no injection of burrow water into the sediment. Enhanced solute exchange by Nereis spp. irrigation (Henriksen et al. 1983, Kristensen 1984, Kristensen \& Hansen 1999) is due to diffusion effects between the burrow and the surrounding porewater (Aller 1982). Porewater profiles from $\mathrm{N}$ microcosms indicated that the greatest effects of irrigation by $N$. diversicolor were in the upper layers of the sediment ment ( $1 \mathrm{mo}$ ) and the diffusive transport distances involved (sediment depths > 20 cm; Aller \& Mackin 1989 , Kristensen \& Hansen 1995), particularly in C microcosms.

As an alternative approach to estimate organic matter decomposition which was not dependent on the assumption of steady state, we summed materials exchanged across the sediment-water interface together with changes in sedimentary and porewater pools. In Tables 3 \& 4 we present budgets for total $\mathrm{O}_{2}$ demand and $\mathrm{CO}_{2}$ production after the addition of macrofauna (Days 1 to 20). In the case of $\mathrm{O}_{2}$, benthic $\mathrm{O}_{2}$ consump-
Table 4. Budgets of total $\mathrm{CO}_{2}$ production for Days 1 to $20 . \mathrm{CO}_{2}$ release is the integrated benthic $\mathrm{CO}_{2}$ flux by the experimental microcosms over the $20 \mathrm{~d}$ period (Fig. 2). Change in porewater $\mathrm{TCO}_{2}(\Delta)$ was calculated as the change in porewater $\mathrm{TCO}_{2}$ concentrations (Fig. 6) in the top $20 \mathrm{~cm}$ from initial concentrations on Day 0 to the end of the experiment. Positive values indicate an accumulation of $\mathrm{CO}_{2}$ in porewaters during the experiment. Benthic respiratory quotients (RQ) were calculated for each microcosm as total $\mathrm{CO}_{2}$ release divided by total $\mathrm{O}_{2}$ demand (Table 5). Values are mean \pm standard error of 1 to 4 replicates. na = not available

\begin{tabular}{|lccll|}
\hline Treatment & $\begin{array}{c}\mathrm{CO}_{2} \\
\text { release }\end{array}$ & $\begin{array}{c}\text { Porewater } \\
\mathrm{TCO}_{2}(\Delta) \\
\left(\mathrm{mmol} \mathrm{C} \mathrm{m}^{-2}\right)\end{array}$ & $\begin{array}{c}\text { Total } \\
\mathrm{CO}_{2}\end{array}$ & $\mathrm{RQ}$ \\
\hline $\mathrm{C}-$ & $823 \pm 37$ & $497 \pm 120$ & $1312 \pm 80$ & $1.36 \pm 0.62$ \\
$\mathrm{~N}-$ & $1854 \pm 270$ & $-81 \pm 188$ & $1773 \pm 343$ & $1.60 \pm 0.16$ \\
$\mathrm{~A}-$ & $3094 \pm 73$ & $-311 \pm 73$ & $2822 \pm 34$ & $1.27 \pm 0.05$ \\
$\mathrm{C}+$ & $1726 \pm 92$ & $1231 \pm 419$ & $2957 \pm 34$ & $1.43 \pm 0.10$ \\
$\mathrm{~N}+$ & $2383 \pm 265$ & $1108 \pm 174$ & $3964 \pm 424$ & $1.65 \pm 0.08$ \\
$\mathrm{~A}+$ & $4742 \pm 258$ & $-279 \pm \mathrm{na}$ & $4221 \pm \mathrm{na}$ & $1.50 \pm$ na \\
& & & &
\end{tabular}


tion was corrected for changes in reduced $S$ species $\left(\mathrm{HS}^{-}, \mathrm{FeS}\right.$ and $\mathrm{FeS}_{2}$ ) in the porewaters and sediments. Total benthic $\mathrm{O}_{2}$ demand provides an estimate of organic matter decomposition when changes in reduced $\mathrm{S}$ pools from anaerobic decomposition are converted to $\mathrm{O}_{2}$ equivalents (Sampou \& Oviatt 1991). The buildup of reduced S compounds (Figs. 5 \& 7 ) was high in $\mathrm{C}$ microcosms, indicating a significant storage of reduced metabolites from anaerobic decomposition. In contrast, there was significant reoxidation of reduced $\mathrm{S}$ species in $\mathrm{N}$ - and $\mathrm{A}$ microcosms. Note, reoxidation of stored sulfides (dissolved or $\mathrm{Fe}$-bound) may have enhanced carbonate dissolution in these microcosms and led to an increase in $\mathrm{CO}_{2}$ production unrelated to organic matter decomposition (Green \& Aller 1998).

Based on total $\mathrm{O}_{2}$ demand and total $\mathrm{CO}_{2}$ production during the $20 \mathrm{~d}$ experiment (Tables 3 \& 4), organic matter decomposition was about 2 times greater with added labile organic matter (total $\mathrm{O}_{2}$ demand for $\mathrm{OM}-$ microcosms averaged $1438 \mathrm{mmol} \mathrm{m}^{-2}$ vs $2388 \mathrm{mmol}$ $\mathrm{m}^{-2}$ in OM+ microcosms, $\mathrm{p} \leq 0.0002$; total $\mathrm{CO}_{2}$ production averaged 1969 and $3708 \mathrm{mmol} \mathrm{m}^{-2}$ in $\mathrm{OM}$ - and $O M+$ microcosms, respectively, $p \leq 0.002$ ). The effects of macrofauna species were independent of the organic matter level (OM $\times$ macrofauna interaction: $p \leq$ 0.36) with Arenicola marina significantly stimulating decomposition approximately 2 -fold relative to $\mathrm{N}$ and $C$ microcosms ( $p \leq 0.006$ and $p \leq 0.0007$, respectively) at both levels of organic matter. Total $\mathrm{O}_{2}$ demand (Table 3), in contrast to benthic $\mathrm{O}_{2}$ fluxes (Table 1), was not significantly different for $\mathrm{N}$ and $\mathrm{C}$ microcosms ( $\mathrm{p} \leq$ 0.30 ). Also, total $\mathrm{CO}_{2}$ production (Table 4) was not significantly different between $N$ and $A$ microcosms ( $\mathrm{p} \leq$ 0.36). Both total $\mathrm{O}_{2}$ uptake and total $\mathrm{CO}_{2}$ production indicate that only $A$. marina significantly stimulated total benthic metabolism and overall organic matter decomposition, whereas both Nereis diversicolor and A. marina significantly enhanced benthic fluxes (Table 1).

While there are many studies documenting the effects of macrofauna on benthic fluxes, fewer studies have directly measured their effects on overall organic matter decomposition. There are a number of indirect indications that macrofauna stimulate organic matter decomposition in general. For example, microbial biomass and activities were stimulated in sediments associated with Arenicola marina burrows (Reichardt 1988). Also. Kristensen \& Blackburn (1987) showed that Nereis virens was capable of stimulating organic matter decomposition by a factor of 2.6 compared to defaunated sediments, and Hansen \& Blackburn (1992) in a nearly identical study demonstrated the same effect (2.1 times stimulation) of an errant polychaete, Nephtys spp. Our results indicated a weaker effect of Nereis diversicolor on organic matter decomposition than expected based on other studies, while the effect of $A$. marina was consistent with other indications and expectations.

\section{Macrofauna effects on microbial metabolism}

Total benthic metabolism can be partitioned into 2 major components, macrofauna respiration and microbial respiration (defined as the difference between total benthic metabolism and macrofauna respiration). Defined in this way 'microbial respiration' may include respiration by other small organisms such as meiofauna, but, given our pretreatment of the sediment (including freezing), we expect most of the benthic respiration that was not due to macrofauna to be due to microbes.

Microbial metabolism (Table 5) was significantly higher in $\mathrm{OM}+$ microcosms than in $\mathrm{OM}-$ microcosms (OM main effect: $p \leq 0.002$ ). Macrofauna respiration accounted for less than $15 \%$ of total benthic metabolism in all cases. There was a tendency for macrofauna to stimulate microbial metabolism, particularly in the A- microcosms, although not significantly ( $p \leq 0.14$ ). Our ability to statistically test these results was hampered by the low number of replicates, especially in the A+treatment, where we were only able to determine microbial respiration for 1 microcosm (Table 5). While not statistically significant, our results are consistent with the contention that macrofauna stimulate total benthic metabolism both by their own respiration
Table 5. Total benthic metabolism, macrofaunal respiration and microbial metabolism. Total benthic metabolism is based on total $\mathrm{CO}_{2}$ production rates (Days 1 to 20, Table 4). Macrofauna respiration was calculated from the allometric relationships in Table 2. 'Microbial' metabolism was estimated as whole system metabolism - macrofauna respiration. Values are given as mean \pm standard error for 1 to 4 microcosms. Faunal induced stimulation represents the contribution of macrofaunal and enhanced microbial respirdtion, respectively, relative to benthic metabolism in the $\mathrm{C}$ microcosms. na $=$ not available

\begin{tabular}{|cccccc|}
\hline Treatment & \multicolumn{2}{c}{$\begin{array}{c}\text { Metabolism } \\
\left(\mathrm{mmol} \mathrm{m}^{-2} \mathrm{~d}^{-1} \text { ) }\right. \\
\text { Total }\end{array}$} & $\begin{array}{c}\text { Faunal induced } \\
\text { stimulation (\%) } \\
\text { Macrofauna }\end{array}$ & Microbial' & Macrofauna 'Microbial' \\
\hline $\mathrm{C}-$ & $69.1 \pm 4.2$ & 0 & $69.1 \pm 4.2$ & - & - \\
$\mathrm{C}+$ & $155.6 \pm 26.5$ & 0 & $155.6 \pm 26.5$ & - & - \\
$\mathrm{N}-$ & $93.3 \pm 18.1$ & $13.5 \pm 0.8$ & $79.8 \pm 17.6$ & +20 & +15 \\
$\mathrm{~N}+$ & $207.7 \pm 22.3$ & $15.2 \pm 0.4$ & $192.5 \pm 22.8$ & +10 & +24 \\
$\mathrm{~A}-$ & $148.5 \pm 1.8$ & $199 \pm 0.6$ & $130.4 \pm 0.7$ & +29 & +89 \\
$\mathrm{~A}+$ & $222.2 \pm \mathrm{na}$ & $23.2 \pm 1.5$ & $201.9 \pm$ na & +15 & +30 \\
\hline
\end{tabular}


and by stimulating the microbial community (e.g Kikuchi 1986, Kristensen \& Blackburn 1987. Hansen \& Blackburn 1992).

There is much debate about the different food sources (e.g. sediment organic matter, bacteria, meiofauna) used by deposit-feeders, but deposit-feeders may compete with microbes to the extent that they both utilize the same organic matter sources in sediments. Also, microbes themselves compose a portion of deposit-feeder diet (Lopez \& Levinton 1987, Grössmann \& Reichardt 1991, Retraubun et al. 1996), indicating a negative trophic relationship between the 2 groups. On the other hand, the activities of macrofauna can increase the availability of substrates (Rhoads 1974, Hansen et al. 1996) and enhance the growth conditions for sediment microbes (Reichardt 1988, Retraubun et al. 1996). These interactions between macrofauna and microbes, both positive and negative, may basically be governed by the availability and degradability of sediment organic matter (Banta 1992, Kristensen et al. 1992).

For Arenicola marina, short gut residence times (Jacobsen 1967) and the low organic content of the ingested sediment suggest a low organic carbon assimilation (Retraubun et al. 1996). The rich meiofauna and microbial community associated with $A$. marina feeding pockets are probably not a sufficient food source alone, however (Plante et al. 1989). The digestive juices in $A$. marina are typical of deposit-feeders and better designed to digest dead organic matter than living cells (Mayer et al, 1997), but A. marina probably utilizes both types of food sources to the extent possible (Grössman \& Reichardt 1991, Retraubun et al. 1996, Riisgård \& Banta 1998). In our experiment, there appeared to be 'extra' organic matter, over that which

Table 6. Integrated SRR for the microcosms at the end of the experiment. Integrated rates were calculated by summing SRR for the top $20 \mathrm{~cm}$ in each microcosm (Fig. 3). Values are given as mean \pm standard error for 2 to 4 microcosms. The percent values for $\mathrm{N}$ and $\mathrm{A}$ microcosms represent the changes in SRR relative to $\mathrm{C}$ - or $\mathrm{C}+$ rates. The amount of total sediment metabolism accounted for by sulfate reduction was calculated assuming that 2 moles of $\mathrm{CO}_{2}$ were released for each mole of $\mathrm{SO}_{4}{ }^{2-}$ reduced. These rates were normalized to total $\mathrm{CO}_{2}$ production rates (Table 4)

\begin{tabular}{|cccc|}
\hline Treatment & $\begin{array}{c}\text { SSR } \\
\left(\mathrm{mmol} \mathrm{m}^{-2} \mathrm{~d}^{-1}\right)\end{array}$ & $\begin{array}{c}\% \\
\text { change }\end{array}$ & $\begin{array}{c}\% \text { total } \\
\text { metabolism }\end{array}$ \\
\hline $\mathrm{C}-$ & $13.5 \pm 7.4$ & & 39 \\
$\mathrm{C}+$ & $45.1 \pm 10.8$ & & 58 \\
$\mathrm{~N}-$ & $4.6 \pm 0.4$ & -66 & 10 \\
$\mathrm{~N}+$ & $43.3 \pm 14.5$ & -4 & 41 \\
$\mathrm{~A}-$ & $7.8 \pm 3.5$ & -42 & 11 \\
$\mathrm{~A}+$ & $6.9 \pm 0.4$ & -85 & 6 \\
\hline
\end{tabular}

A. marina utilized themselves, allowing an increase in microbial metabolism in both types of sediments.

Nereis diversicolor can readily assimilate sediment organic matter (Cammen 1980, Vedel, Lopez, Kristensen \& Banta unpubl.), implying a competitive interaction with sediment microbes at the sediment surface where they forage. Microbes deeper in the sediment are more likely to be stimulated by $N$. diversicolor irrigation, however (Henriksen et al. 1983). Our results suggest that microbial metabolism was slightly stimulated by $N$. diversicolor with only limited deposit-feeding macrofauna-microbe competition occurring. Thus, while deposit-feeding macrofauna and microbes probably compete for some organic matter resources, the 2 species of macrofauna we studied here appeared to increase the availability of food resources and enhance growth conditions for sediment microbes to some extent.

\section{Macrofauna effects on anaerobic metabolism}

In contrast to their effects on total benthic and microbial metabolism, both macrofauna species had negative effects on anaerobic metabolism (Table 6). Not surprisingly, anaerobic metabolism was higher with added organic matter level ( $\mathrm{p} \leq 0.002$ ), but the contribution of anaerobic metabolism to total benthic metabolism was lower in all microcosms with macrofauna present ( $p \leq 0.03$ ). The effect of macrofauna was dependent on the level of organic matter, however ( $p \leq$ 0.03 ). Arenicola marina had an strong inhibitory effect on anaerobic metabolism, holding SRR at the same low level in both OM- and OM+microcosms (A-vs $A+: p \leq$ $0.99)$. The effect of $A$. marina was most dramatic at high organic matter levels where SRR were significantly lower than the control ( $C+v s A+: p \leq 0.02$ ). The inhibition of sulfate reduction by $A$. marina was less dramatic and not significant in unamended sediments (C-vs A-: $\mathrm{p} \leq 0.99$ ).

The effects of Nereis diversicolor on anaerobic metabolism were weaker. N. diversicolor appeared to inhibit sulfate reduction to a greater extent at lower organic matter levels, although SRR were not significantly different from rates in $\mathrm{C}$ microcosms at either level of organic matter (C-vs $\mathrm{N}-, \mathrm{p} \leq 0.56$; $\mathrm{C}+\mathrm{vs} \mathrm{N}+$, $\mathrm{p} \leq 0.99$ ). The nearly identical rates of SRR in $\mathrm{C}+$ and $\mathrm{N}+$ were somewhat coincidental, as SRR were low deep in $\mathrm{C}+$ microcosms (Fig. 3) due to $\mathrm{SO}_{4}{ }^{2-}$ depletion (Fig. 7), while SRR were low in the upper sediment layers of $\mathrm{N}+$ microcosms due to bioturbation by $N$. diversicolor (Fig. 3)

Among uncertainties in the determination of sulfate reduction in these bioturbated sediments are underestimations due to reoxidation and comparisons of SRR 
determined at the end of the experiment with total benthic metabolism estimated over a longer time period (19 d). Measurements of SRR using long radiotracer incubations (>10 to $30 \mathrm{~min}$ ) in oxidized sediment layers may lead to an underestimate of the true rates due to reoxidation of reduced ${ }^{35} \mathrm{~S}$ to ${ }^{35} \mathrm{SO}_{4}{ }^{2-}$ (Moeslund et al. 1994, Fossing 1995). The extent of such a reoxidation was probably limited, however, in the control and $\mathrm{N}$ + sediments as dissolved sulfides were present in the porewaters. Sulfate reduction may also be underestimated in bioturbated sediments due to oxidation of deeper layers. Reoxidation of reduced sulfides was evident in the $\mathrm{N}$ - and both A treatments as TRS pools decreased during the experiment and DS levels were very low. Nielsen (1997) documented significant reoxidation of ${ }^{35} \mathrm{~S}$ in sediments bioturbated by Arenicola marina. Underestimations of SRR due to reoxidation of up to 4 - to 8 -fold have been suggested in some cases (Moeslund et al. 1994, Nielsen 1997). If there were similar high levels of reoxidation in the A microcosms, then anaerobic metabolism was significantly more important in sediments inhabited by $A$. marina than we estimated here.

The effect of Nereis diversicolor was to displace sulfate reduction into deeper sediment layers. While there was the potential that SRR was underestimated in the upper layers of $\mathrm{N}$ microcosms where $N$. diversicolor is most active, the estimates of SRR at depth in $\mathrm{N}$ microcosms are likely to be accurate. The importance of reoxidation of sulfides during radiotracer experiments must be addressed in future studies if we are to fully understand the effects of macrofauna on anaerobic decomposition in benthic environments.

The second potential uncertainty with our assessment of the importance of anaerobic metabolism was that overall benthic metabolism at the end of the experiment may have been lower than earlier in the experiment. As such, a comparison of total benthic metabolism (averaged over $20 \mathrm{~d}$ ) to SRR measured at the end of the experiment may have been biased in favor of aerobic metabolism. SRR estimated from $\mathrm{SO}_{4}{ }^{2-}$ depletion suggest that SRR had slowed down. Both of these problems may have led to an underestimate of the importance of anaerobic metabolism in some treatments, but the general tendencies and effects of these macrofauna species on anaerobic metabolism are still clear.

Macrofaunal effects on anaerobic decomposition processes have only been addressed by few. Hines \& Jones (1985) and Aller \& Yingst (1980) suggested that macrofauna bioturbation stimulates SRR by mixing labile organic matter into anaerobic zones. Furthermore, Aller (1978) and Aller \& Yingst (1985) concluded that macrofauna indirectly stimulate anaerobic decomposition by removing metabolites, or by supplying electron acceptors or microbial substrates. Our results suggest the opposite effect for the 2 species examined, i.e. that they inhibit anaerobic decomposition while simultaneously stimulating aerobic decomposition. The only evidence of a possible indirect stimulation of anaerobic decomposition was in the $\mathrm{N}+$ treatment, where SRR rates were low in the upper sediment layer, but were high at depth. Nereis diversicolor apparently stimulated sulfate reduction by ensuring an adequate supply of $\mathrm{SO}_{4}{ }^{2-}$ to the deeper sediment layers.

It is clear that the 2 macrofauna species studied here affect the balance between aerobic and anaerobic microbial metabolisms to the benefit of the former. Our results indicate that Arenicola manna is more effective than Nereis diversicolor in stimulating aerobic microbial metabolism at the expense of anaerobic metabolism. We attribute these effects to the oxidizing effects of these macrofauna due to their irrigation. Recent work by Nielsen (1997) supports our observation that sulfate reduction is reduced in sediments immediately surrounding $A$. marina burrows (within ca $5 \mathrm{~mm}$ ). On the other hand, he observed stimulation of SRR in the sediment layers further away $(5$ to $20 \mathrm{~mm}$ ) from the burrows. Similar stimulation of SRR associated with burrows of Mya arenaria was documented by Hansen et al. (1996). Both of these studies demonstrate that the net effect of macrofauna on anaerobic decomposition is a balance of several effects which may counteract each other.

The overall effects of macrofauna on anaerobic processes are dependent on the species (with its particular mode of living) and the environment considered (e.g. levels of organic matter or overall rates of metabolism). The 2 species we studied here are both common and represent 2 typical modes of living for infauna, i.e. head-down deposit-feeding and deep irrigation in the case of Arenicola marina and surface deposit-feeding and burrow ventilation in the case of Nereis diversicolor. Our findings can therefore be generalized to infauna with similar modes of living. The effects of macrofauna with other modes of life on anaerobic decomposition need to be investigated separately, however. Furthermore, we should investigate how communities (assemblages of species) of macrofauna interact to affect anaerobic processes.

The overall balance of aerobic versus anaerobic metabolism depends on the depth of the metabolically active sediment column. If amount and degradability of organic matter had decreased with depth in our microcosms as is more often the case in nature, then anaerobic decomposition would play a smaller role in total organic matter decomposition. In such a case, any reduction in the importance of anaerobic decomposition due to macrofauna would be less significant. If, on the other hand, there is a large pool of refractory 
organic matter in the deeper anaerobic layers, then an injection of $\mathrm{O}_{2}$ into these layers by bioturbation will enhance decomposition processes (Kristensen et al. 1995). Similarly, transport of more labile organic matter to the deeper sediment layers due to bioturbation (Hines \& Jones 1985) would increase the importance of anaerobic decomposition.

\section{Community respiratory quotients}

Benthic community respiratory quotients (RQs), calculated as the ratio of total $\mathrm{CO}_{2}$ production to total $\mathrm{O}_{2}$ demand, were slightly greater than the expected value of 1 in all microcosms (Table 4), indicating the presence of anaerobic decomposition processes, where $\mathrm{CO}_{2}$ is released without consuming $\mathrm{O}_{2}$, and the storage of reduced products such as sulfides within the sediments (e.g. Hargrave \& Phillips 1981, Andersen \& Hargrave 1984). Such imbalance between benthic $\mathrm{CO}_{2}$ production and $\mathrm{O}_{2}$ consumption is usually temporary (i.e. seasonal) because most of the reduced products are reoxidized at some point in time consuming $\mathrm{O}_{2}$, either directly or indirectly (Canfield et al. 1993). We expected to find RQs close to 1 because we included changes in sediment and porewater pools of reduced S compounds in our calculations. It is possible that storage of other reduced compounds such as reduced Fe or Mn could account for the slightly elevated RQs. The sandy organic-poor sediments used in this study were likely to be poor in $\mathrm{Fe}$ and $\mathrm{Mn}$, however, and thus the role of metal cycling is expected to be minor. Also, RQs for the macrofauna themselves were calculated to be greater than 1, but macrofauna respiration contributed only a fraction ( 7 to $15 \%$ ) of the total community respiration.

The community $R Q$ can also vary depending on the degree of oxidation of $\mathrm{NH}_{4}{ }^{+}$released during decomposition or the composition of the organic matter being degraded. The expected $\mathrm{RQ}$ would be 0.77 if all $\mathrm{NH}_{4}{ }^{+}$ produced was oxidized to $\mathrm{NO}_{3}^{-}$using $\mathrm{O}_{2}$ in contrast to 1 if all remineralized $\mathrm{N}$ remained as $\mathrm{NH}_{4}{ }^{+}$(Froelich et al. 1979). Also, Anderson et al. (1986) calculated expected RQs ranging between 0.6 and 1.1 based on varying the $\mathrm{C} / \mathrm{N}$ ratio of organic matter being decomposed (from 6.6 to 17 ). The organic matter decomposed in our microcosms would be required to have an extremely low C/N ratio (2 to 3) to yield the high RQs we observed. Consequently, there must have been significant storage of reduced compounds other than TRS and DS or there was significant dissolution of carbonate that added to $\mathrm{TCO}_{2}$ production (Anderson et al 1986) to yield the high RQs we observed. Carbonate dissolution due to sulfide oxidation, as was seen in the $\mathrm{N}$ - and A microcosms, would increase the measured
RQ (Green \& Aller 1998). It is most likely, however, that the true explanation is a combination of the above mechanisms. Note, RQs calculated from benthic fluxes alone (Table 1) gave similar values greater than 1 (1.14 to 1.44$)$

\section{Reduced sulfur pools and reoxidation-effects of macrofauna}

The increase in TRS pools and the presence of DS in the sediment of the $\mathrm{C}$ and $\mathrm{N}+$ microcosms are similar to findings in coastal sediments with limited bioturbation and high organic content (Thode-Andersen \& Jørgensen 1989, Moeslund et al. 1994). The increase in TRS and DS corresponded to 88 and $41 \%$ of the sulfide produced during the course of the experiment in $\mathrm{C}$ and $\mathrm{C}+$ microcosms, respectively, indicating high rates of sulfide burial. In $\mathrm{N}+$ microcosms sulfide burial was $20 \%$, which is more typical of that found in coastal sediments (Thode-Andersen \& Jørgensen 1989, Jørgensen et al. 1990, Moeslund et al. 1994).

The reduced TRS pools and low DS levels in the other treatments ( $\mathrm{N}_{-}, \mathrm{A}-$ and $\mathrm{A}+$ ) indicated that there was a net reoxidation of buried reduced $S$ pools. Others (Hansen et al. 1996, Nielsen 1997) have measured similar net reoxidation of TRS pools in highly bioturbated sediments. Reoxidation was most intense in the A microcosms, where Arenicola marina affected the reduced $\mathrm{S}$ pools throughout the entire sediment column. A significant reoxidation of TRS at depth in sediments containing $A$. marina was also observed by Nielsen (1997), confirming the effect of this deep bioturbator on the sediment S cycle. Nereis diversicolor had more limited effects, reoxidizing reduced $S$ species in the upper sediment layers as long as production rates were moderate. The deeper sediments in $\mathrm{N}$ microcosms were reduced, however, and dominated by anaerobic decomposition.

\section{Biogeochemical roles of Arenicola marina and Nereis diversicolor}

A summary of the effects of these 2 macrofauna species on sediment processes and biogeochemistry is presented in Table 7 . Both macrofauna species enhance benthic fluxes of solutes between sediments and the overlying water. This is due to enhanced flushing of porewater solutes by both species and stimulation of total benthic metabolism, especially by Arenicola marina. Total benthic metabolism is increased, although only slightly in the case of Nereis diversicolor, by the direct contribution of the macrofauna themselves as well as by an enhancement of microbial 
Table 7. Summary of effects of the macrofauna species Nereis diversicolor and Arenicola marina on sediment biogeochemical processes and parameters. Effects are shown for both sediment types (OM- and $\mathrm{OM}+$ ) used in the experiment. (介) Stimulation or enhancement; (لl) inhibition or reduction the number of symbols indicates the strength of the effect ( 1 significant, but $<100 \%$ change $_{2} 2:>100 \%$ change; and so forth). 0: No effects; non-significant trends are indicated in parentheses

\begin{tabular}{|c|c|c|c|c|}
\hline \multirow[t]{2}{*}{ OM level } & \multicolumn{2}{|c|}{ ereis diversicolor } & \multicolumn{2}{|c|}{ Arenicola marina } \\
\hline & - & + & - & + \\
\hline \multicolumn{5}{|l|}{ Benthic fluxes } \\
\hline $\mathrm{CO}_{2}$ & $\Uparrow$ & $\Uparrow$ & $\Uparrow \Uparrow$ & $\pi \Uparrow$ \\
\hline $\mathrm{O}_{2}$ & $\Uparrow$ & $\Uparrow$ & $\Uparrow \Uparrow$ & $\Uparrow \Uparrow$ \\
\hline \multicolumn{5}{|l|}{ Metabolism } \\
\hline Total $\mathrm{CO}_{2}$ & $(\Uparrow)$ & $(\Uparrow)$ & $\Uparrow \Uparrow$ & $\Uparrow$ \\
\hline Total $\mathrm{O}_{2}$ & 0 & $(\Uparrow)$ & $\Uparrow \Uparrow$ & $\Uparrow$ \\
\hline Microbial & $(\Uparrow)$ & $(\Uparrow)$ & $\Uparrow$ & $(\Uparrow)$ \\
\hline Anaerobic & $\Downarrow$ & 0 & (d) & $\Downarrow$ \\
\hline \multicolumn{5}{|l|}{ Sediment and porewaters } \\
\hline $\begin{array}{l}\text { Dissolved metabolites } \\
\left(\text { e.g. } \mathrm{TCO}_{2}\right)\end{array}$ & $\Downarrow$ & 0 & $\Downarrow \downarrow$ & $\lfloor\downarrow \downarrow$ \\
\hline Reduced S species & $\Downarrow$ & $(\downarrow)$ & $\downarrow \downarrow$ & $\Downarrow \downarrow$ \\
\hline $\begin{array}{l}\text { Overlying water solutes } \\
\left(\text { e.g. } \mathrm{SO}_{4}^{2-}\right)\end{array}$ & $s \uparrow$ & $(\Uparrow)$ & $\Uparrow \Uparrow$ & $\Uparrow \pi \Uparrow$ \\
\hline
\end{tabular}

metabolism. Both species inhibit anaerobic metabolism and alter sediment $\mathrm{S}$ cycles, though to different degrees.

Based on our results, sediments inhabited by Arenicola marina have low levels of metabolites and are highly flushed and oxidized despite high rates of benthic metabolism (both microbial and macrofaunal). Much of the sediment metabolism will be aerobic. In contrast, sediments inhabited by Nereis diversicolor will have variable, possibly high, concentrations of metabolites, especially at depth. Both aerobic and anaerobic metabolism will likely occur in sediments inhabited by $N$. diversicolor, although the balance between the 2 may differ between environments. In the case of $N$. diversicolor, the biogeochemical nature of the sediment depends on the balance of metabolite production rates (i.e. organic matter decomposition), removal and oxidation due to $N$. diversicolor bioturbation.

Cohesive sediments without significant macrofauna undoubtedly have high concentrations of metabolites. This is still the case even with low rates of metabolism, such as in the C-microcosms, because the removal of metabolites from sediments by diffusion alone is a slow process (e.g Berner 1980). Furthermore, anaerobic decomposition most likely dominates in such sediments. Macrofauna are thus very important for affecting the biogeochemical conditions of the environments in which they live. We still need to improve our understanding of the effects of macrofauna on sediment microbial activity, however. In particular, more work is needed on the role of macrofauna in controlling the relative importance of aerobic and anaerobic metabolic processes in benthic environments.

Acknowledgements. The authors would like to thank Susan Andreasen, Hanne Brandt, Pernille Greve and Ove Larsen for technical help with the analyses and Vibeke Møller for practical help during the experiment. This manuscript was significantly improved after comments by Mark Green and 2 anonymous reviewers. This study was partially supported by a NATO Postdoctoral Science Fellowship to G.T.B., a Danish Scientific Research Council grant (SNF grant no. 9601423) to E.K. and by a grant to M.H.J. and E.K. from the German Ministry of Research (BMBF) as part of the SWAP ecosystems project (Sylter Wattenmeer Austausch Prozesse).

\section{LITERATURE CITED}

Aller RC (1978) Experimental studies of changes produced by deposit feeders on pore water, sediment, and overlying water chemistry. Am J Sci 278:1185-1234

Aller RC (1980) Relationships of tube-dwelling benthos with sediment and overlying water chemistry. In: Tenore KR, Coull BC (eds) Marine benthic dynamics. Univ of South Carolina Press, Columbia, p 285-308

Aller RC (1982) The effects of macrobenthos on chemical properties of marine sediment and overlying water. In: McCall PL, Tevesz MJS (eds) Animal-sediment relations. Plenum Press, New York, p 53-102

Aller RC, Mackin JE (1989) Open-incubation, diffusion methods for measuring solute reaction rates in sediments. J Mar Res 47:411-440

Aller RC, Yingst JY (1978) Biogeochemistry of tubedwellings: a study of the sedentary polychaete Amphitrite onata (Leidy). J Mar Res 36:201-254

Aller RC, Yingst JY (1980) Relationships between microbial distributions and the anaerobic decomposition of organic matter in surface sediments of Long Island Sound, USA. Mar Biol 56:29-42

Aller RC, Yingst JY (1985) Effects of marine deposit-feeders Heteromastus filiformis (Polychaeta), Macoma balthica (Bivalvia), and Tellina texana (Bivalva) on averaged sedimentary solute transport, reaction rates, and microbial distributions. J Mar Res 43:615-645

Andersen $F \varnothing$, Hargrave BT (1984) Effects of Spartina detritus enrichment on aerobic/anaerobic benthic metabolism in an intertidal sediment. Mar Ecol Prog Ser 16:161-171

Andersen Fø, Kristensen $E$ (1988) The influence of macrofauna on estuarine benthic community metabolism: a microcosm study. Mar Biol 99:591-603

Anderson LG, Hall POJ, Iverfeldt $A$, Rutgers van der Loeff MM, Sundby B. Westerlund SFG (1986) Benthic respiration measured by total carbonate production. Limnol Oceanogr 31:319-329

Banta GT (1992) Decomposition and nitrogen cycling in coastal marine sediments-controls by temperature, organic matter inputs, and benthic macrofauna. PhD thesis, Boston Univ

Berner RA (1980) Early diagenesis. A theoretical approach Princeton University Press, Princeton, NJ

Blackburn TH, Blackburn ND (1993) Rates of microbial processes in sediments. Philos Trans R Soc Lond A 344:49-58 
Cammen LM (1980) The significance of microbial carbon in the nutrition of the deposit feeding polychaete Nereis succinea. Mar Biol 61:9-20

Canfield DE (1993) Organic matter oxidation in marine sediments. In: Wollast R, Mackenzie FT, Chou L (eds) Interactions of $C, N, P$ and $S$ biogeochemical cycles. SpringerVerlag, Berlin, p 333-363

Canfield DE, Jørgensen BB, Fossing H, Glud R, Gundersen J, Ramsing NB, Thamdrup B, Hansen JW, Nielsen LP, Hall POJ (1993) Pathways of organic oxidation in three continental margin sediments. Mar Geol 113:27-40

Cline JD (1969) Spectrophotometric determination of hydrogen sulfide in natural waters. Limnol Oceanogr 14: $454-458$

Colijn F, de Jonge VN (1984) Primary production of microphytobenthos in the Ems-Dollard Estuary. Mar Ecol Prog Ser 14:185-196

Doering PH, Kelly JR, Oviatt CA, Sowers T (1987) Effect of the hard clam Mercenaria mercenaria on benthic fluxes of inorganic nutrients and gases. Mar Biol 94:377-383

Fenchel T (1996) Worm burrows and oxic microniches in marine sediments. 2. Distribution patterns of ciliated protozoa. Mar Biol 127:297-301

Flach EC, Beukema JJ (1994) Density-governing mechanisms in populations of the lugworm Arenicola marina on tidal flats. Mar Ecol Prog Ser 115:139-149

Fossing $\mathrm{H}$ (1995) 35S-Radiolabeling to probe biogeochemical cycling of sulfur. In: Vairavamurthy MA, Schoonen MAA. (eds) Geochemical transformations of sedimentary sulfur, Vol 612. American Chemical Society, Washington, DC, p 348-364

Fossing $\mathrm{H}$, Jørgensen BB (1989) Measurement of bacterial sulfate reduction in sediments: evaluation of a single-step chromium reduction method. Biogeochemistry 8:205-222

Froelich PN, Klinkhammer GP, Bender ML, Luedke NA, Heath GR, Cullen D, Dauphin P, Hammond D, Hartman B, Maynard V (1979) Early oxidation of organic matter in pelagic sediments of the eastern equatorial Atlantic: suboxic diagenesis. Geochim Cosmochim Acta 43:1075-1090

Graf G (1992) Benthic-pelagic coupling: a benthic view. Oceanogr Mar Biol Annu Rev 30:149-190

Green MA. Aller RC (1998) Seasonal patterns of carbonate diagenesis in nearshore terrigenous muds: relation to spring phytoplankton bloom and temperature. J Mar Res 56:1097-1123

Grössmann S, Reichardt W (1991) Impact of Arenicola marina on bacteria in intertidal sediments. Mar Ecol Prog Ser 77 : 85-93

Hall POJ, Aller RC (1992) Rapid, small-volume, flow injection analysis for $\sum \mathrm{CO}_{2}$ and $\mathrm{NH}_{4}{ }^{*}$ in marine and freshwaters. Limnol Oceanogr 37:1113-1119

Hansen K, Kristensen E (1997) Impact of macrofaunal recolonization on benthic metabolism and nutrient fluxes in a shallow marine sediment previously overgrown with macroalgal mats. Estuar Coast Shelf Sci 45:613-628

Hansen K, King GM, Kristensen E (1996) Impact of the softshell clam Mya arenaria on sulfate reduction in an intertidal sediment. Aquat Microb Ecol 10:181-194

Hansen LS, Blackburn TH (1992) Mineralization budgets in sediment microcosms: effect of the infauna and anoxic conditions. FEMS Micrabiol Ecol 102:33-43

Hargrave BT (1973) Coupling carbon flow through some pelagic and benthic communities. I Fish Res Board Can 30:1317-1326

Hargrave BT, Phillips GA (1981) Annual in situ carbon dioxide and oxygen flux across a subtidal marine sediment. Estuar Coast Shelf Sci 12:725-737
Heip C, Herman R (1979) Production of Nereis diversicolor O F. Müller (Poylchaeta) in a shallow brackish-water pond. Estuar Coast Mar Sci 8:297-305

Henriksen K, Rasmussen MB, Jensen A (1983) Effect of bioturbation on microbial nitrogen transformations in the sediment and fluxes of ammonium and nitrate to the overlying water. Ecol Bull 35:193-205

Hines ME, Jones GE (1985) Microbial biogeochemistry and bioturbation in the sediments of Great Bay, New Hampshire. Estuar Coast Shelf Sci 20:729-742

Hüttel M (1990) Influence of the lugworm Arenicola marina on porewater nutrient profiles of sand flat sediments. Mar Ecol Prog Ser 62:241-248

Jacobsen VH (1967) The feeding of the lugworm, Arenicola marina (L.). Ophelia 4:91-109

Jensen KM, Jensen MH, Kristensen E (1996) Nitrification and denitrification in Wadden Sea sediments (Königshafen, Island of Sylt, Germany) as measured by nitrogen isotope pairing and isotope dilution. Aquat Microb Ecol 11: $181-191$

Jørgensen BB (1978) A comparison of methods for the quantification of bacterial sulfate reduction in coastal marine sediments. I. Measurements with radiotracer techniques. Geomicrobiol J 1:11-27

Jørgensen BB (1996) Material flux in the sediment. In: Jørgensen BB, Richardson K (eds) Eutrophication in coastal marine ecosystems, Vol 52. American Geophysical Union, Washington, DC, p 115-135

Jorgensen BB, Bang M, Blackburn TH (1990) Anaerobic mineralization in marine sediments from the Baltic Sea-North Sea transition. Mar Ecol Prog Ser 59:39-54

Kikuchi E (1986) Contribution of the polychaete, Neanthes japonica (Izuka), to the oxygen uptake and carbon dioxide production of an intertidal mud-flat of the Nanakita River Estuary, Japan. J Exp Mar Biol Ecol 97:81-93

Kristensen E (1981) Direct measurement of ventilation and oxygen uptake in three species of tubicolous polychaetes (Nereis spp.). J Comp Physiol 145:45-50

Kristensen E (1983) Ventilation and oxygen uptake by three species of Nereis (Annelida: Polychaeta). II. Effects of temperature and salinity changes. Mar Ecol Prog Ser 12: 299-306

Kristensen E (1984) Effect of natural concentrations on nutrient exchange between a polychaete burrow in estuarine sediment and the overlying water. J Exp Mar Biol Ecol 75: $171-190$

Kristensen E (1985) Oxygen and inorganic nitrogen exchange in a Nereis virens (Polycheata) bioturbated sedimentwater system. J Coast Res 1:109-116

Kristensen $E$, Andersen $F \varnothing$ (1987) Determination of organic carbon in marine sediments: a comparison of two CHN-analyzer methods. J Exp Mar Biol Ecol 109:15-23

Kristensen E, Blackburn TH (1987) The fate of organic carbon and nitrogen in experimental marine sediment systems: influence of bioturbation and anoxia. $J$ Mar Res 45: $231-257$

Kristensen E, Hansen K (1995) Decay of plant detritus in organic-poor marine sediment: production rates and stoichiometry of dissolved $\mathrm{C}$ and $\mathrm{N}$ compounds. J Mar Res 53: $675-702$

Kristensen E, Hansen K (1999) Transport of carbon dioxide and ammonium in bioturbated (Nereis diversicolor) coastal, marine sediments. Biogeochemistry 45:147-168

Kristensen E, Andersen FØ, Blackburn TH (1992) Effects of benthic macrofauna and temperature on degradation of macroalgal detritus: the fate of organic carbon. Limnol Oceanogr 37:1404-1419 
Kristensen E, Ahmed SI, Devol AH (1995) Aerobic and anaerobic decomposition of organic matter in marine sediment: Which is faster? Limnol Oceanogr 40:1430-1437

Kristensen E, Jensen MH, Jensen KM (1998) Sulfur dynamics in sediments of Königshafen. In: Gätje $C$, Reise $K$ (eds) Ökosystem Wattenmeer-Austausch-, Transport- und Stoffumwandlungsprozesse. Springer-Verlag, Berlin, p 233-256

Lopez GR, Levinton JS (1987) Ecology of deposit-feeding animals in marine sediments. Q Rev Biol 62:235-260

Mackin JE, Swider KT (1989) Organic matter decomposition pathways and oxygen consumption in coastal marine sediments. J Mar Res 47:681-716

Mayer LM, Schick LL, Self RFL, Jumars PA, Findlay RH, Chen Z, Sampson S (1997) Digestive environments of benthic macroinvertebrate guts: enzymes, surfactants and dissolved organic matter. J Mar Res 55:785-812

Meyer-Reil LA (1983) Benthic response to sedimentation events during autumn to spring at a shallow station in the Western Kiel Bight. II. Analysis of benthic bacterial populations. Mar Biol 77:247-256

Meyers MB, Fossing H, Powell EN (1987) Microdistribution of interstitial meiofauna, oxygen and sulfide gradients, and the tubes of macro-fauna. Mar Ecol Prog Ser 35:223-241

Milliken GA, Johnson DE (1984) Analysis of messy data, Vol 1. Design of experiments. Chapman \& Hall, New York

Moeslund L, Thamdrup B, Jørgensen BB (1994) Sulfur and iron cycling in a coastal marine sediment: radiotracer studies and seasonal dynamics. Biogeochemistry 27 : $129-152$

Nielsen OI (1997) Sandormens (Arenicola marina) betydning for svovlkredsløbet i tidevandssedimenter. (The lugworm Arenicola marina's importance for the sulfur cycle in intertidal sediments.) MS thesis, Institute of Biology, Odense University

Pelegrí SP, Blackburn TH (1995) Effect of bioturbation by Nereis sp., Mya arenaria and Cerastoderma sp. on nitrification and denitrification in estuarine sediments. Ophelia 42:289-299

Pelegrí SP, Nielsen LP, Blackburn TH (1994) Denitrification in estuarine sediment stimulated by the irrigation activity of the amphipod Corophium volutator. Mar Ecol Prog Ser 105:285-290

Plante CJ, Jumars PA, Baross JA (1989) Rapid bacterial growth in the hindgut of a marine deposit feeder. Microb Ecol 18:29-44

Editorial responsibility: Gary M. King

Walpole, Maine, USA
Rasmussen AD, Banta GT, Andersen O (1998) Effects of bioturbation by the lugworm Arenicola marina on cadmium uptake and distribution in sandy sediments. Mar Ecol Prog Ser 164:179-188

Reichardt W (1988) Impact of bioturbation of Arenicola marina on microbiological parameters in intertidal sediments. Mar Ecol Prog Ser 44:149-158

Retraubun ASW, Dawson M, Evans SM (1996) The role of the burrow funnel in feeding processes in the lugworm Arenicola marina (L.). J Exp Mar Biol Ecol 202:107-118

Rhoads DC (1974) Organism-sediment relations on the muddy sea floor. Oceanogr Mar Biol Annu Rev 12: $223-300$

Riisgård HU (1991) Suspension feeding in the polychaete Nereis diversicolor. Mar Ecol Prog Ser 70:29-37

Riisgård HU, Banta GT (1998) Irrigation and deposit feeding by the lugworm Arenicola marina, characteristics and secondary effects on the environment. A review of current knowledge. Vie Milieu

Riisgård HU, Berntsen I, Tarp B (1996) The lugworm (Arenicola marina) pump: characteristics, modelling and energy cost. Mar Ecol Prog Ser 138:149-156

Rijken M (1979) Food and food uptake in Arcnicola marina. Neth J Sea Res 13:406-421

Sampou P, Oviatt CA (1991) A carbon budget for a eutrophic marine ecosystem and the role of sulfur metabolism in sedimentary carbon, oxygen and energy dynamics. J Mar Res 49:825-844

Skogland T, Lomeland S, Goksøyr J (1988) Respiratory burst after freezing and thawing of soil: experiments with soil bacteria. Soil Biol Biochem 20:851-856

Suess E (1980) Particulate organic carbon flux in the oceanssurface productivity and oxygen utilization. Nature 288; $260-263$

Thode-Andersen S, Jørgensen BB (1989) Sulfate reduction and the formation of $35 \mathrm{~S}$-labeled $\mathrm{FeS}, \mathrm{FeS}_{2}$, and $\mathrm{S}^{0}$ in coastal marine sediments. Limnol Oceanogr 34:793-806

Vedel A, Riisgård HU (1993) Filter-feeding in the polychaete Nereis diversicolor: growth and bioenergetics. Mar Ecol Prog Ser 100:145-152

Wheatcroft RA, Jumars PA, Smith CR, Nowell ARM (1990) A mechanistic view of the particulate biodiffusion coefficient: step lengths, rest periods and transport directions. J Mar Res 48:177-207

Zar JH (1984) Biostatisical analysis, 2nd edn. Prentice-Hall, Engelwood Cliffs, NJ

Submitted: September 10, 1998; Accepted: January 27, 1999 Proofs receuved from author(s): September 10, 1999 